\title{
Molecular Biomarkers of Anthropic Impacts in Natural Archives: A Review
}

\author{
Nathalie Dubois ${ }^{1 *}$ and Jérémy Jacob ${ }^{2,3,4}$ \\ ${ }^{1}$ Surface Waters Research and Management, Eidgenössische Anstalt für Wasserversorgung, Abwasserreinigung und \\ Gewässerschutz, Dübendorf, Switzerland, ${ }^{2}$ Institut des Sciences de la Terre d'Orléans, UMR 7327, Université d'Orléans, \\ Orléans, France, ${ }^{3}$ Centre National de la Recherche Scientifique/National Institute for Earth Sciences and Astronomy, Institut \\ des Sciences de la Terre d'Orléans, UMR 7327, Orléans, France, ${ }^{4}$ Bureau de Recherche Géologique et Minière, Institut des \\ Sciences de la Terre d'Orléans, UMR 7327, Orléans, France
}

OPEN ACCESS

Edited by: Simon Haberle

Australian National University, Australia

Reviewed by:

Mark Bush,

Florida Institute of Technology, USA Krystyna Magdalena Saunders, Australian Nuclear Science and Technology Organisation, Australia

*Correspondence:

Nathalie Dubois

nathalie.dubois@eawag.ch

Specialty section:

This article was submitted to

Paleoecology,

a section of the journal

Frontiers in Ecology and Evolution

Received: 10 May 2016

Accepted: 20 July 2016

Published: 03 August 2016

Citation:

Dubois N and Jacob J (2016)

Molecular Biomarkers of Anthropic Impacts in Natural Archives: A Review.

Front. Ecol. Evol. 4:92.

doi: 10.3389/fevo.2016.00092
Molecular biomarkers are becoming increasingly important tools in paleoenvironmental research, and over recent years have been shown to be useful indicators of human activities. Common indicators of past human impacts include pollen, charcoal, sedimentation rates, and magnetic susceptibility, each of which has its limitations. Thus, the advent of novel molecular markers of human activities provides an additional set of tools to make the difficult distinction between anthropogenic and natural factors that have influenced the environment in the past. Fossil biomarkers preserved in natural archives provide valuable temporal and spatial insights on land use such as cultivation practices and pastoral activities, post-harvesting activities (e.g., retting), and their consequences on the environment and ecosystems. Herein we review the progress that has been made in developing novel biomarkers of human activities, differentiating those indicating environmental changes that can be related to human activities from those unambiguously attributable to human activities. The review ends with a case study highlighting the strengths and weaknesses of the biomarker approach and finally summarizes opportunities for future research.

Keywords: biomarkers, human impacts, natural archives, fossil molecules, paleoenvironment, land use change

\section{INTRODUCTION}

Increasing awareness of early human impacts on the landscape led to the "early Anthropocene" concept (Ruddiman, 2013; Zalasiewicz et al., 2015). This "Palaeoanthropocene" period is characterized by small and regional effects. It is currently hotly debated whether the Palaeoanthropocene should be considered part of the Anthropocene and if they form a new Epoch of geological time (Foley et al., 2013). Indeed, human societies have modified a significant portion of Earth's surface since the advent of agriculture. Land use has shaped terrestrial ecosystems and impacted aquatic ones for millennia. Traditionally, the presence of humans and their activities were mostly investigated in and around archaeological sites, where they are most evident. In more recent times, archaeological investigations have also started to consider the wider cultural landscape, trying for instance to reconstruct past agricultural activities, such as the subdivision of the fields and cultivation types (e.g., Guilaine, 1991, 2000).

Past landscape changes are classically investigated in natural archives, such as sedimentary deposits, by chemical analysis (Giguet-Covex et al., 2011), physical analysis (e.g., seismic 
reflection lines, magnetic susceptibility, Anselmetti et al., 2007; Arnaud et al., 2012) or microfossil identification (Tinner et al., 2003), but can also be detected by organic geochemistry (Noël et al., 2001). Unfortunately, agricultural activities left few traces that prove the past cultivation of a plant at a given site, with the exception of phytoliths (Harvey and Fuller, 2005) macrofossils from cerealia are often fragile and unrecognizable, and their pollen are dispersed over a large area. When macrofossil indicators are not available or the plant material is too badly decomposed for the recognition of macrofossils, molecular fingerprints offer an alternative to reconstruct the plant organic matter input (Andersson et al., 2011). These molecular markers or "biomarkers" (i.e., fossil molecules of known and restricted biological source) have recently gained attention. Ideally, a biomarker would have a structure unique to one specific species. In practice, biomarkers commonly used have one overwhelmingly dominant source in a given environmental context (Bossard et al., 2013).

Paleoenvironmental records based on biomarker distribution and/or isotopic composition have been produced from a variety of archives, such as peat cores (e.g., Pancost et al., 2002), lake sediment cores (e.g., Jacob et al., 2008a; Simonneau et al., 2013), loess (e.g., Xie et al., 2002), and bat guano deposits (e.g., Wurster et al., 2010). These fossil molecules are resistant to biodegradation (e.g., Brocks and Summons, 2004), surviving passage through the digestive systems of animals largely unchanged, and travel through the Earth system for thousands to millions of years (e.g., Eglinton and Calvin, 1967; Brocks and Pearson, 2005; Garel et al., 2014). The most specific biomarkers have recently become powerful tools to trace human activities such as land-use (e.g., Fisher et al., 2003; Jacob et al., 2008a; Lavrieux et al., 2013; Simonneau et al., 2013; Guillemot et al., 2015), and are reviewed here.

In this review we will mostly focus on biomarker records from lacustrine sedimentary sequences, as these provide the best continuous high-resolution records of anthropogenic environmental disturbances. Lakes can be considered as integrative sinks, both of large-scale environmental changes induced by climate and of local anthropogenic activities (e.g., Meyers, 2003; Oldfield and Dearing, 2003; Dearing et al., 2006). In addition, biomarkers found in lake sediments provide not only an overall view of the conditions that prevailed in the catchment, but also of the conditions within the lake itself. In favorable cases, they are not only able to detect a human impact within the catchment, but also the consequences on the whole ecosystem.

In this paper we distinguish biomarkers that reflect environmental changes, which can be caused by human activities or have a natural component (Section Biomarker Evidence of Environmental Changes that can be Linked to Human Disturbances) from those clearly specific to certain human activities (Section Unambiguous Biomarkers of Human Activities). The record of the former ones can sometimes be difficult to distinguish from climatically driven environmental changes.

\section{BIOMARKER EVIDENCE OF ENVIRONMENTAL CHANGES THAT CAN BE LINKED TO HUMAN DISTURBANCES}

This section reviews biomarkers that are not unequivocal proof of a human impact. Changes in the distribution and concentration of these biomarkers are usually linked to human activity based on additional information from complementary data. However, such changes (e.g., fire, catchment erosion) can also occur when no human impact is responsible, for instance at times of significant natural climatic shifts.

\section{Biomass Burning}

The initial settlement of humans in a location, in particular "slash and burn" land clearance practices associated with agricultural development, is habitually detected in paleoecological records as an increase in macroscopic charcoal particles (e.g., Glikson, 2013). Charcoal analysis provides insights into wood-burning practices, but is restricted by the size of identifiable particles (Lehndorff et al., 2014). In addition, this approach has spatial and temporal limitations, is affected by secondary deposition up to several years later, and does not directly detect fire intensity (Denis et al., 2012). A number of molecular markers such as levoglucosan and benzene polycarboxylic acids (BPCA) have been proposed recently for the quantification of pyrogenic carbon in fire-impacted soils and sediments (Elias et al., 2001; D'Anjou et al., 2012; Lehndorff et al., 2014).

The signatures and concentrations of organic compounds in smoke aerosols from the controlled burning of agricultural, silvicultural, and garden vegetation have been shown to vary according to burn temperature, flame structure, pile density, moisture content, and vegetation/biomass type (Freeman and Cattell, 1990; Oros and Simoneit, 2001; García-Falcón et al., 2006; Denis et al., 2012). Since the biomarkers and their combustion alteration products are source-specific, they can be used as tracers for determining fuel type and source contributions from biomass burning. Oros and Simoneit (2001) showed that the major organic components directly emitted to smoke particulate matter from conifers were straight chain aliphatic compounds from vegetation wax and diterpenoid acids from resin. The major natural products altered by combustion included derivatives from phenolic (lignin), monosaccharide (cellulose) biopolymers, and oxygenated and aromatic products from diterpenoids. Finally, other biomarkers present as minor components included phytosterols, unaltered high molecular weight wax esters and polycyclic aromatic hydrocarbons (PAH).

Vane et al. (2013) assessed the transfer pathways of PAH between upland peats subject to managed burning and reservoir sediments in South Yorkshire, England. These authors observed that the major transfer pathway is in the particulate form (i.e., suspended sediment) rather than the dissolved form. In addition, the PAH signatures of the recently formed, shallow peat samples were strongly correlated with those of the sediment core samples, suggesting that the former are a dominant source for the latter. Similarly, Denis et al. (2012) showed that PAH fluxes in annually varved lacustrine sediments from the Yosemite National Park 
(USA) record the observational fire history within $0.5 \mathrm{~km}$ of the lake. Low molecular weight PAHs (e.g., fluoranthene, pyrene, and benz[a]anthracene; Supplementary Figure 1) were found to be the best recorders of fire, whereas high molecular weight PAHs recorded fire intensity.

PAHs can also be derived from vegetation and its decayed remains during early diagenetic processes (Wakeham et al., 1980; Malawska et al., 2002) or from atmospheric deposition of industrial emissions (Sanders et al., 1995). A simultaneous rise in phenanthrene $(\mathrm{PAH})$ in Lake Michigan (USA) and Lake Ontario (USA) around 1900 has for instance been attributed to high temperature combustion of coal for steel production (see Figure 11 by Meyers, 2003). The correspondence between the phenanthrene maxima in the 1950s and use of coal suggests that airborne distribution of industrial stack gases and particles has distributed PAHs across the Great Lakes region with, however, significant contributions from local sources.

Schüpbach et al. (2015) combined macroscopic charcoal and the molecular fire markers levoglucosan, mannosan, and galactosan to investigate Holocene fire history in the Maya Lowlands of Petén (Guatemala). The authors detected three periods of high fire activity during the Holocene: 9500-6000, 3700 , and $2700 \mathrm{cal}$ year BP. The first period of high fire activity was attributed to climate conditions, but interestingly, all three molecular fire indicators show an earlier increase compared to charcoal for the first peak. The authors suggest that the earlier increase of the molecular markers might be a result of low temperature and smoldering fires prevailing over the entire region of Mesoamerica during the early Holocene. This signal would have been captured less efficiently by the sedimentary charcoal record, which is mostly a local fire indicator. The fire maximum around $3700 \mathrm{cal}$ year BP might already be influenced by early anthropogenic agricultural activities in the region, based on the fast decrease in the relative abundance of wooden charcoal (Schüpbach et al., 2015). The youngest fire maximum $(2700 \mathrm{cal}$ year BP) was linked to the agricultural activity of the Maya at Lake Petén Itzá. It lies well within the "Maya Clay layer," which corresponds to the interval with the maximum soil erosion rate (Anselmetti et al., 2007).

This biomarker approach might prove useful to distinguish between wild fires that flare during drought years and intentional fires lit independently of climate conditions. Analyses of 11 $\mathrm{PAH}$ compounds in the particulate matter produced by burning various Australian woods and leaves under different conditions showed that large scale uncontrolled bush fires produced much higher relative amounts of benzo(a)pyrene, the most toxic of the parent $\mathrm{PAH}$ compounds, than other combustion sources (Freeman and Cattell, 1990).

\section{Vegetation Shifts}

Pollen has long been used to identify early human impacts on the landscape. It is possible to evaluate characteristic vegetation shifts resulting from land clearance and to identify pollen from cultivated plants or weeds associated with human-disturbed landscapes (Behre, 1981). Lignin phenols and plant waxes (long chain $n$-alkanes and $n$-alkanoic acids) are molecules characteristic of vascular plants, and therefore can serve as biomarkers for terrestrial plants (Feng et al., 2013). Their resistance to biodegradation makes them excellent biomarkers as they pass into the environment in and on leaf fragments and as aerosols formed by wind abrasion and fires (Eglinton and Eglinton, 2008). Plant waxes can be transported from land to their sedimentary repository in lakes and oceans within days to weeks (Eglinton and Eglinton, 2008). The chain length distribution and their carbon isotopic composition reflect the vegetation present, in particular the $\mathrm{C} 3-\mathrm{C} 4$ plant distribution (Chikaraishi et al., 2004; Rommerskirchen et al., 2006).

$n$-Alkane distributions in sediments provide an approximate record of the kinds of plants that have populated the watershed (Meyers, 2003). In watersheds where grasses dominate, C31 is the major sedimentary $n$-alkane, whereas C27 and C29 are more abundant in lake sediments where trees dominate (Cranwell, 1973). The average chain length (ACL) is commonly used to evaluate the relative contribution of trees, shrubs, and herbs (Peltzer and Gagosian, 1989):

$$
\left.\mathrm{ACL}_{27-33}=\Sigma\left(\left[\mathrm{C}_{i}\right]\right) \times i\right) / \Sigma\left[\mathrm{C}_{i}\right]
$$

where $\left[C_{i}\right]$ is the concentration of the $n$-alkane with carbon number $i$, over the range $27-33$.

Ternary plots of the relative proportions of the C27, C29, and C31 $n$-alkanes in sediments can be used to reconstruct past abundances of grasses, shrubs, coniferous, and deciduous trees in the vicinity of a lake (e.g., Schwark et al., 2002).

Fisher et al. (2003), for instance, showed an extremely close correspondence between the mean carbon number of (C27C31) $n$-alkanes and the percentage of pollen derived from grass in the sediments of Gormire Lake (UK). Thermochemolysis of lignin confirmed that there was a significant change from woody to grass-dominated material deposited in the lake sediments, contemporaneous with a first deforestation event at $\sim 600 \mathrm{BC}$. Changes in both the sedimentary $\mathrm{C} / \mathrm{N}$ ratios and yields of ligninderived phenols suggest that deforestation events at $\sim 600 \mathrm{BC}$ and $\mathrm{AD} 1200$ led to enhanced aquatic productivity, initially through the development of reed-swamp vegetation.

A less typical example comes from a stalagmite record from Ethiopia. Preserved stalagmite plant-derived $n$-alkanes and $n$-alkanols show clear changes in composition over time, related to known land-use changes in the area (Blyth et al., 2007). Clearance of the original shrub and woody vegetation in the 1930s to make way for agriculture is reflected as a decrease in the C27/C31 n-alkane ratio, which is a simple expression of the ACL (Marseille et al., 1999).

More specific molecular markers of vascular plants have been proposed to track changes in terrestrial vegetation. Tricyclic diterpenes (Supplementary Figure 1) are considered to be mainly derived from gymnosperms (Simoneit et al., 1985), whereas pentacyclic triterpenes with oleanane, ursane, or lupane structure (Supplementary Figure 1) are mostly produced by angiosperms (Abe et al., 1993). Other pentacyclic triterpenes, such as those with a fernane or arborane structure (Supplementary Figure 1), are distributed between angiosperms and ferns, and potentially bacteria (Hauke et al., 1992a,b; Jaffé and Hausmann, 1995). Within major vascular groups, even more specific molecular 
biomarkers, mostly pentacyclic triterpenes, have recently been developed (see next section).

\section{Herbs and Grasses}

Pentacyclic triterpenes methyl ethers (PTMEs; Supplementary Figure 1) have been shown to be specific to Graminae (Jacob et al., 2005), and triterpenyl acetates (pentacyclic triterpenes bearing an acetate group; Supplementary Figure 2) have been shown to be mainly produced by plants such as Asteraceae, which live in open areas (Lavrieux et al., 2011).

Among triterpenyl acetates, friedelanyl acetate was found to be abundant in soils under Ericaceae and, although present in other taxa, could constitute a valuable tracer for this plant family (Trendel et al., 2010; Zocatelli et al., 2014). Other pentacyclic triterpenyl acetates are far less common, including pichierenyl, isopichierenyl, gammacerenyl, and swertenyl acetates that are only reported, up to now, in a single Asteraceae species (Picris hieracioides; Lavrieux et al., 2011). The evolution of pentacyclic triterpenyl acetates in lake sediments could be of great interest for deciphering the evolution of landscapes under human pressure. In Lake Aydat (Massif Central, France) sediments, their distribution through time matched the recent history of Asteraceae in the region (Lavrieux, 2011).

PTMEs and acetates are now being more frequently detected in lacustrine sediments and in peats (Grimalt et al., 1991; Logan et al., 1995; van Bergen et al., 1997; Jacob et al., 2005; Xu et al., 2008; Oyo-Ita et al., 2010; Trendel et al., 2010; Zocatelli et al., 2010; Zocatelli et al., 2014; Lavrieux, 2011; Schwab et al., 2015).

Interestingly, iso- and anteiso-monomethyl alkanes were reported in aromatic and culinary plants from the Lamiaceae (mint) family (Huang et al., 2011). However, these compounds have never been detected in lake sediments and their potential to track the cultivation of such plants thus remains to be demonstrated.

\section{Trees and Shrubs}

For gymnosperms, Le Milbeau et al. (2013) demonstrated that compounds with a serratane structure associated with at least one methoxyl group (Supplementary Figure 3) are exclusively encountered in the Pinaceae, while other serratanetype compounds are more widely distributed. To date, these methoxy-serratenes have not yet been identified in lacustrine sedimentary archives. Their detection could help unravel the evolution (afforestation, deforestation) of pine forests under natural or anthropogenic stress. Similarly, triterpenes related to betulin and their diagenic biproducts (Supplementary Figure 1) are increasingly used as tracers for Betula or Alnus spp. (Regnery et al., 2013; Zocatelli et al., 2014; Galeron et al., 2016).

The ursolic acid (Supplementary Figure 1) record in the sediments of Gormire Lake (UK) exhibits a strong relationship with that of tree-shrub pollen, leading the authors to propose this compound as a tracer for trees and shrubs (Fisher et al., 2003).

It is worthwhile noting that, considering the large structural diversity of methoxy-serratenes and triterpenyl acetates, more precise chemotaxonomical relationships between given compounds or groups of compounds and taxa can be expected, possibly at the species level. This would allow, for example, discriminating between Pinaceae species used in forestry or cultivated Asteraceae.

Last but not least, the recent application of DNA metabarcoding to lake sediments has proven its potential to trace past vegetation cover (Parducci et al., 2012).

\section{Soil Erosion}

Forest clearings, land-use practices, and grazing by livestock often diminish catchment soil stability, causing detrital events that are reflected in sedimentary basins as magnetic susceptibility maxima, higher amounts of detrital elements (e.g., Dearing, 2008; Debret et al., 2010; Arnaud et al., 2012; Magny et al., 2013) higher sedimentation rates, and changes in grain size distribution. However, higher erosion rates can clearly also be associated with increased precipitation. Thus, the link to human activities needs to be made based on additional indicators.

Recently, Jacob et al. (2009) proposed a new molecular biomarker of soil erosion: Trimethyl tetrahydrochrysene (TTHC) a diagenetic derivative of oleanane-type pentacyclic triterpenes (Wakeham et al., 1980). TTHC profiles reconstructed in Lake Le Bourget (France) sediment revealed increased soil erosion linked to the arrival of new agricultural practices during the Bronze Age in the lake catchment (see also Section Cultivation, Figure 1). This compound was similarly used by Guillemot et al. (in review) to track soil erosion due to recent agropastoral pressure around Lake Igaliku (Greenland). However, the assumption that TTHC arises from degradation of pentacyclic triterpenes in litters and soils (Wakeham et al., 1980) remains to be demonstrated, since we have not yet been able to detect TTHC in several litter and soil samples.

Another type of biomarker, branched glycerol dialkyl glycerol tetraethers (brGDGTs) are regarded as specific biomarkers for soil, as they are allegedly formed by soil bacteria (Hopmans et al., 2004). The Branched and Isoprenoid Tetraether (BIT) index was thus created to reconstruct the contribution of soil organic matter to marine and lacustrine sediments. It is based on the relative abundance of brGDGTs, representing terrestrial organic matter, and crenarchaeol, representing aquatic organic matter (Hopmans et al., 2004). Although brGDGTs were also found to be produced in situ in lakes, means exist to determine the significance of in situ production (Naeher et al., 2014). The BIT index could thus represent a potential marker for increased soil erosion caused by human land-use, but to our knowledge it has never been applied as such.

\section{Water Quality Degradation}

Organic matter in lacustrine sediments is derived from production within the aquatic system, inputs of terrestrial material from the surrounding lake catchment and bacterial production within the sediments themselves (Prartono and Wolff, 1998). The relative importance of these sources is determined by local factors such as climate, nutrient supply, hydrodynamic conditions, and the biogeochemistry of the lake sediments. Human perturbations in a catchment often result in an increase in primary productivity in the aquatic ecosystem downstream. In sedimentological records, such increases are reflected in the C:N ratio as well as the $\delta^{13} \mathrm{C}$ of organic matter, 
A

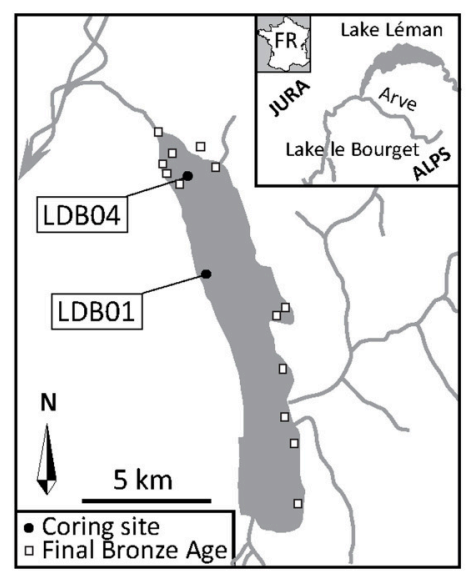

B

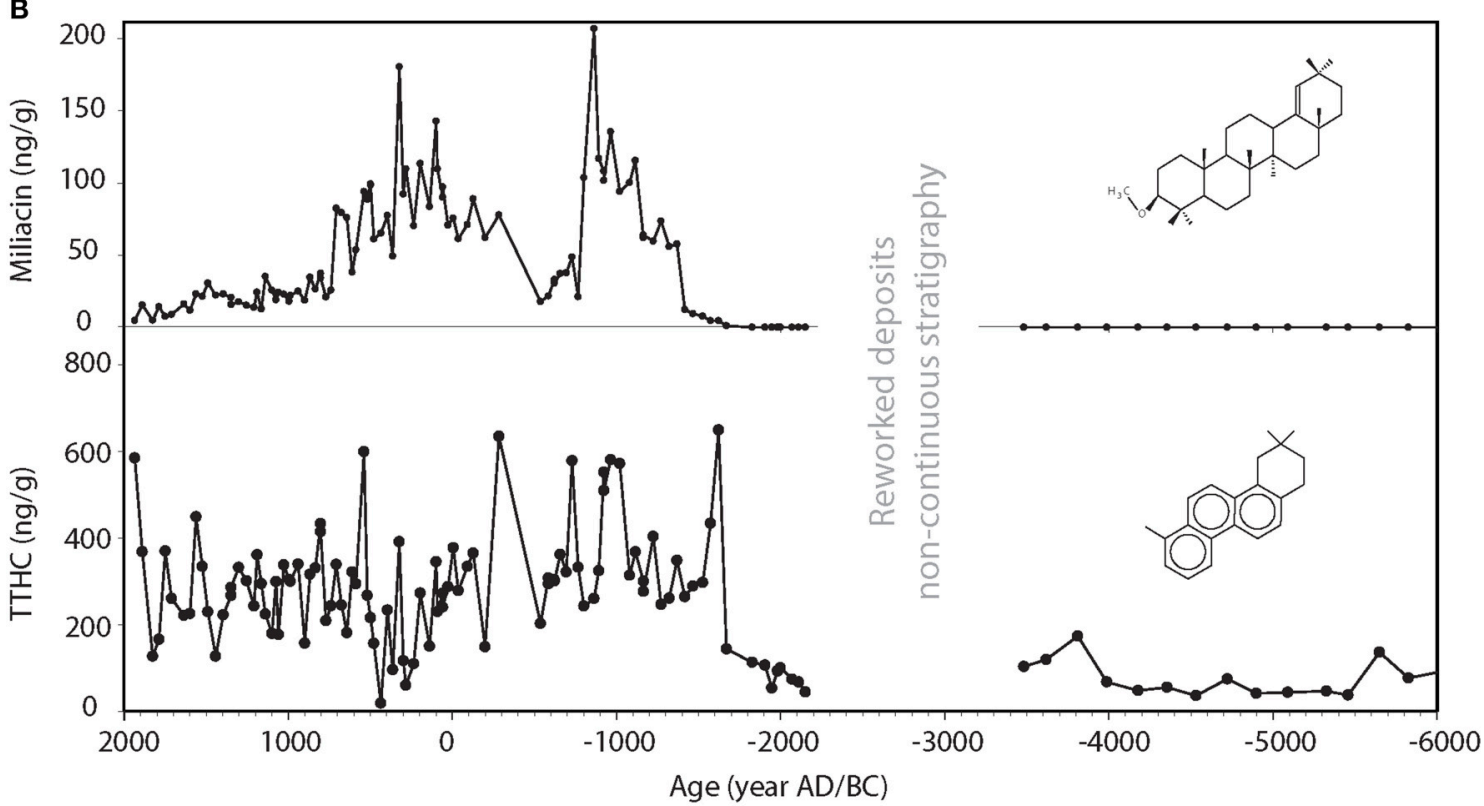

FIGURE 1 | (A) Location of Lake le Bourget with coring sites and of Bronze Age archaeological sites. (B) Evolution of miliacin and TTHC concentrations (with structures) in core LDB04. Modified from Jacob et al. (2009).

which trace the relative contributions of terrestrial and aquatic organic matter (Massa et al., 2012). In addition, diatom-based trophic reconstructions have been used to track the impacts of past land use on water quality (e.g., Miras et al., 2015).

Algal and microbial biomarker records can also reflect changes in aquatic ecosystems. Whereas odd long chain $n$ alkanes (C27, C29, C31) are major constituents of terrestrial plants (see Section Vegetation shifts), short chain $n$-alkanes (C15, C17, C19) are produced by many phytoplankton species (Cranwell, 1982). The abundance of short chain $n$-alkanes has thus been used to reconstruct lacustrine paleoproductivity rates (Meyers, 2003), and the ratio of terrigenous to aquatic $n$-alkanes or $\mathrm{TAR}_{(\mathrm{HC})}$ was defined by Bourbonnière and Meyers (1996) to determine the relative contribution of terrestrial vs. aquatic OM:

$\mathrm{TAR}_{\mathrm{HC}}=(\mathrm{C} 27+\mathrm{C} 29+\mathrm{C} 31) /(\mathrm{C} 15+\mathrm{C} 17+\mathrm{C} 19)$
Silliman and Schelske (2003), for instance, documented a dramatic drop in the $\mathrm{TAR}_{\mathrm{HC}}$, which indicates a shift from macrophyte to algal dominance of organic matter production, in Lake Apopka (USA). This trophic shift followed agricultural development of the watershed in the mid-1940s and reflects increased nutrient delivery to the lake.

Similar to $n$-alkanes, sterols can be used to evaluate the proportion of allochtonous to autochtonous organic matter. In this case, the ratio of $\mathrm{C}_{29} / \mathrm{C}_{27(\mathrm{ST})}$ is used, where $\mathrm{C} 29$ is mostly synthesized by terrestrial higher plants (as $\beta$-sitosterol), whereas the C27 sterols are derived from cholesterol, which has essentially an aquatic origin (Nishimura and Koyama, 1977; Muri et al., 2004). Prartono and Wolff (1998), for instance, observe increases in concentrations of unsaturated and branched chain fatty acids, phytol, and C27 and C28 sterols toward the surficial sediments of lake Rostherne Mere (UK), suggesting 
that the autochthonous contribution to sedimentary organic matter has increased as a result of the recent eutrophication. Isotopic carbon composition and $\mathrm{C} / \mathrm{N}$ ratios support the increasing inputs of autochthonous organic matter toward surficial sediments. Interestingly, the authors note that elevated levels of relatively reactive autochthonous organic matter in the shallower sediments and the resulting reducing conditions in the water column have led to a change in the diagenetic reactions prevailing in the sediments.

Last but not least, the proportion of allochtonous vs. autochtonous organic matter and the redox potential in sediments has been suggested to control the microbial reduction of sterols in sediments (Nishimura, 1977). The $5 \alpha(\mathrm{H})$-stanols $/ \Delta^{5}$-sterols ratio is thus used to monitor changes in redox potential, and has been defined as:

$$
\begin{aligned}
5 \alpha(\mathrm{H})- & \text { stanols } / \Delta^{5}-\text { sterols }=(\text { cholestanol }+ \text { campestanol } \\
& + \text { stigmastanol }+ \text { sitostanol }) /(\text { cholesterol } \\
& + \text { campesterol }+ \text { stigmasterol }+\beta-\text { sitosterol })
\end{aligned}
$$

As an example, Bertrand et al. (2012) used a suite of molecular ratios to identify the different developmental steps of a watershed, from a swamp to the progressive settlement of a pond in the Lorraine region (France). Several transitions are clearly recorded, especially drying or high water level phases, as well as the extension of the forest cover in the watershed. Interestingly, draining and dredging of the sediment in 2002 resulted in a redox change (an oxic event) $15 \mathrm{~cm}$ below the 2002 horizon.

\section{UNAMBIGUOUS BIOMARKERS OF HUMAN ACTIVITIES}

\section{Cultivation}

In palynological records, the appearance of Cerealia pollen (Behre, 1981) or Zea mays pollen in Mesoamerica (e.g., Pohl et al., 2007) is often used to detect the beginning of cultivation practices. The biomarker approach can be especially useful in places were pollen are poorly preserved, or for plants that are difficult to identify in palynological records. For instance, whereas the distinction between Cannabis and Humulus (hop genus) pollen grains requires morphometric analyses due to their resemblance (Whittington and Gordon, 1987; Mercuri et al., 2002), cannabinol allows a clear differentiation, as this organic molecule is specific to hemp (Lavrieux et al., 2013). The palynological record of cultivated taxa may also be skewed in tropical Pacific insular ecosystems where settlers consistently cut the flowers of introduced plants (taro and yam) to simulate tuber growth (Combettes et al., 2015).

The molecule miliacin is a prime example of such an approach. Jacob et al. (2008a,b) demonstrated that sedimentary miliacin (olean-18-en-3 $\beta$-ol methyl ether) was the only PTME specific to the broomcorn millet. Bossard et al. (2013) later confirmed that seeds of broomcorn millet are sedimentary miliacin's dominant source, thus its detection in lacustrine sediments indicates that this PTME is produced in significant amounts in the catchment. Jacob et al. (2009) used miliacin to track the cultivation of broomcorn millet (Panicum milliaceum) in the catchment of Lake le Bourget (France, Figure 1). As millet is an allochtonous plant introduced by humans in the region, this organic molecule is unambiguously indicative of human activities. Their records show that the onset of millet cultivation coincides with the onset of major soil erosion in the catchment during the Middle Bronze Age $(\sim 1800$ BC; Figure 1). It is worth noting that the beginning of millet cultivation was not associated with major vegetation changes in the catchment (Gauthier and Richard, 2009; Jacob et al., 2009). Only pollen data from the Late Bronze Age showed significant disturbances. Millet fields were probably restrained in area (the catchment is very steep and colonized by conifers), and probably not larger than those used during the Neolithic. But these highly productive hot spots of miliacin production in the catchment were efficient enough to be recorded in the sediment.

Simonneau et al. (2013) found an almost synchronous first appearance of miliacin in the sediments of Lake Paladru (France, $\sim 1600 \mathrm{BC}$ ), revealing that millet cultivation was a regional practice but diachronously imported in the Alps. Miliacin has also been detected in Ukrainian paleosols, where it was likewise interpreted as a tracer of former millet cultivation (Motuzaite-Matuzeviciute et al., 2016). In this particular case, the use of molecular biomarkers helped to disentangle the origin of charred cereal grain remains in pits that were not associated with any local settlement. High levels of miliacin in ancient soils stratigraphically connected to the pits proved that millet was cultivated locally and not being brought from other locations by mobile groups (Motuzaite-Matuzeviciute et al., 2016).

Organic geochemical studies of soils under experimental control and paleosols have shown that compound specific $\delta^{15} \mathrm{~N}$ of amino acids reveal early land use practices (Simpson et al., 1999b). Despite the rapidly decomposing nature of the amino acid fraction in soils, the signal demonstrates differences between manured grassland, unmanured grassland and continuous cereal cultivation (Simpson et al., 1999b). Amino acids such as valine, alanine, leucine, and isoleucine are isotopically lighter where grassland soils have not been manured in comparison to manured areas. In addition, $\delta^{15} \mathrm{~N}$ values are lighter under cereals and heavier under grassland. Relict soils from the Mediaeval Period and fossil soils from the Bronze Age from Orkney retain a $\delta^{15} \mathrm{~N}$ signal typical of heavily manured soils.

In more recent times, Zocatelli et al. (2010) used changes in grass specific biomarkers to trace turf production around Lagoa do Boqueirão (Brazil) for football stadiums and golf courses. The increase in PTME concentrations in the lake sediments during the period 1996-2000 results mainly from high amounts of a compound tentatively assigned as arbor-8-en-3ßol ME, a potential diagenetic derivative of cylindrin produced by Zoysia japonica, a grass introduced for turf cultivation (Figure 2).

Novel biomarkers specific to introduced species could thus provide additional indicators for the domestication and spreading of certain cultivation. Of interest could be the isoand anteiso-monomethyl alkanes reported in plants from the mint family (see Section Vegetation shifts above). In addition, biochemical investigations can provide useful information on past land-use, especially when settlements or macrobotanical remains are absent (Motuzaite-Matuzeviciute et al., 2016). 

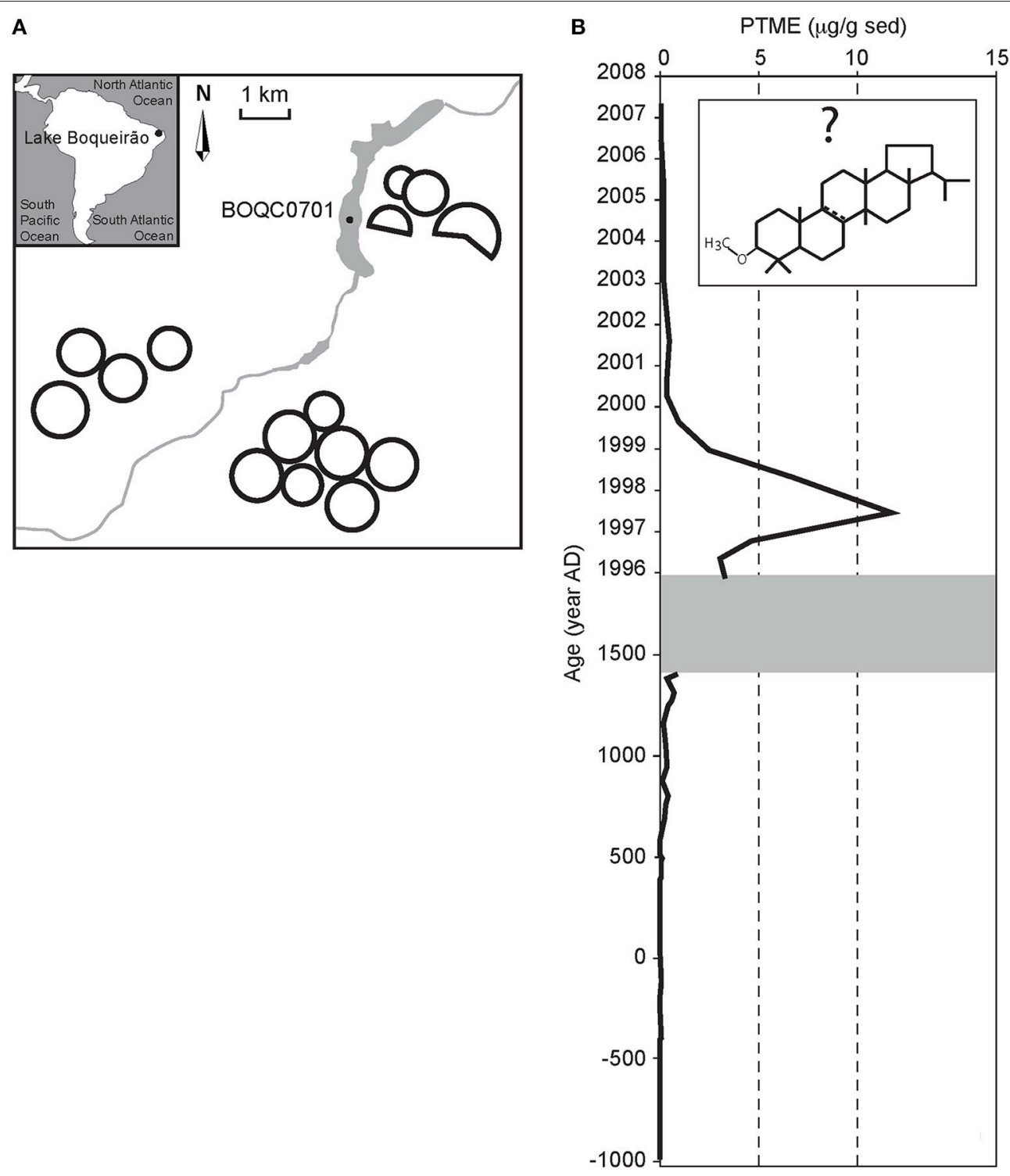

FIGURE 2 | (A) Location of Lake Boqueirão (Northern Brazil) with coring site and sketch of the catchment illustrating irrigation circles. (B) Evolution of a pentacyclic triterpene methyl ether (with proposed structure) in the sediments of Lake Boqueirão attesting the recent installation of turf cultivation in the catchment. Modified from Zocatelli et al. (2010).

\section{Hemp Retting}

Hemp, along with millet, is one of the oldest cultivated plants. Ancient societies used hemp for food, medicine, and to produce ropes, paper, and clothes (Russo, 2007). Hemp retting, the process of submersion of hemp stems to facilitate the extraction of its fibers, was tracked in Lake Aydat sediments (France) using cannabinol (Lavrieux et al., 2013; Figure 3). This biomarker allowed the palynological challenge of discriminating hemp cultivation from hemp retting to be overcome. Cannabinol allows not only tracing a type of cultivation, but also the postharvest processing of cultivated material by humans. Strong environmental after effects are inherent to its use: hemp retting leads to dramatic alteration of water quality (Lavrieux et al., 2013). Hemp retting likely influenced some bacterial communities dynamics (Miras et al., 2015).

\section{Pastoral Activities}

The domestication of animals has long been a determinant factor in the modification of landscapes (Diamond, 2002). Spores of the dung fungus Sporormiella recovered from natural archives have been used to trace the extinction of the North American megafauna during the Late Pleistocene, as well as the introduction of livestock (i.e., modern grazing herbivores) during the historic period (Davis and Shafer, 2006; Raper and Bush, 2009). The application of Sporormiella as a proxy for herbivore presence and abundance is however complicated by 


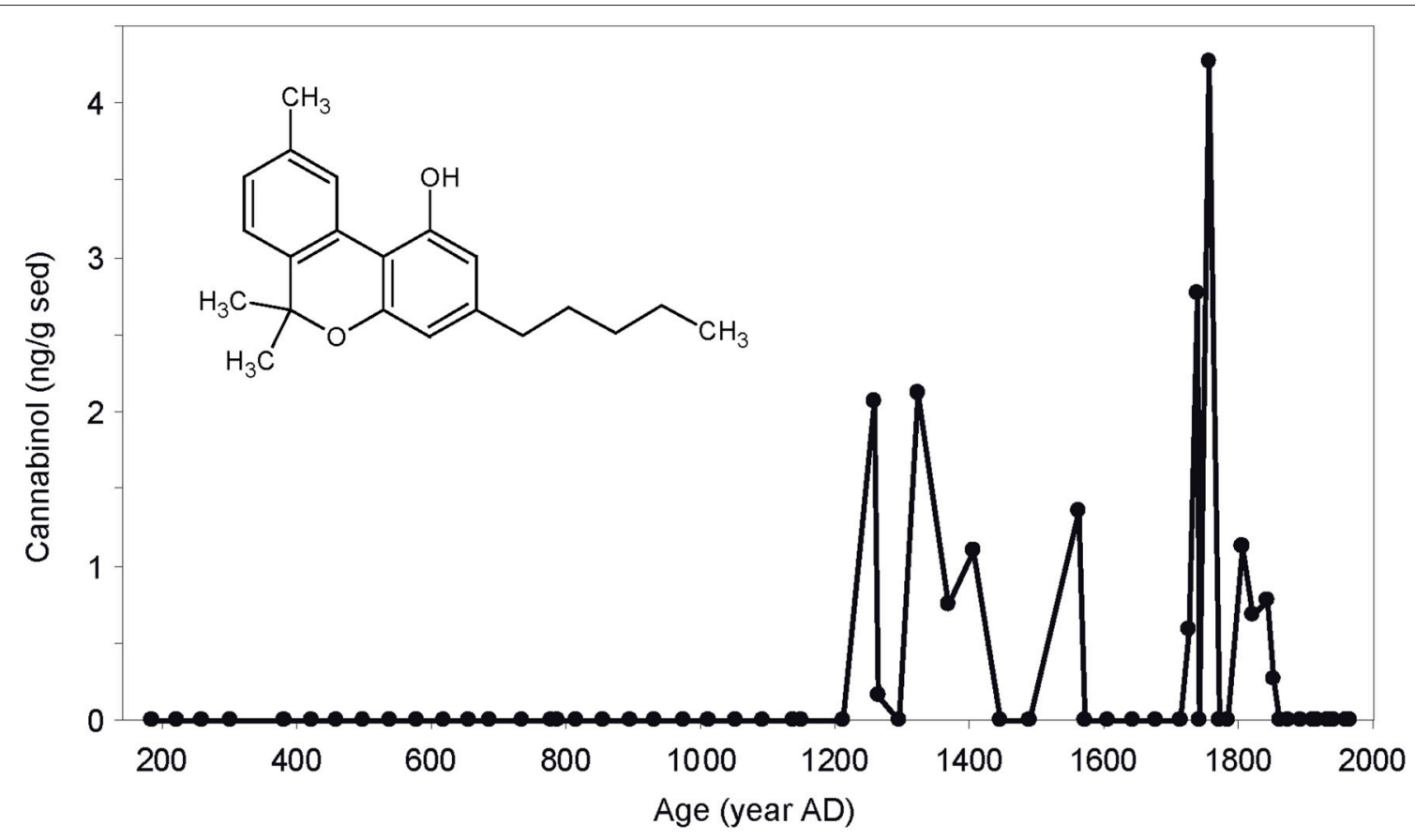

FIGURE 3 | Evolution of cannabinol (structure shown) concentration in the sediments of Lake Aydat since AD 200. Modified from Lavrieux et al. (2013).

its spatially sensitive representation: the spores decline sharply with increasing distance from the dung source (Raper and Bush, 2009). Sporormiella spores are released close to the ground and have a gelatinous sheath that facilitates spore attachment on nearby vegetation, thus hampering their dispersion.

Fecal markers such as stanols and bile acid have been used as biomarker indicators for the detection of grazing in a catchment (e.g., D'Anjou et al., 2012). 5 $\beta$-stanols are organic compounds produced by the microbially mediated alteration of cholesterol in the intestinal tracts of most mammals, making them ideal fecal biomarkers. Bull et al. (2002) proposed the following ratio to distinguish between omnivore (pig/human) and ruminant species: (coprostanol + epicoprostanol/ $5 \beta$-stigmastanol + epi$5 \beta$-stigmastanol), where coprostanol ( $5 \beta$-cholestan-3 $\beta$-ol) is mainly produced by humans and $5 \beta$-stigmastanol serves as the biomarker of herbivore fecal matter. Fecal markers have the advantage of dispersing more widely than spores of Sporomiella.

Bile acid products of gut flora can be used to distinguish human contributions from those of pigs: hyodeoxycholic acid is a biomarker of pig feces, whereas human feces are dominated by deoxycholic acid and lithocholic acid (Simpson et al., 1999a).

Guillemot et al. (2015), for instance, reconstructed the evolution of livestock in southwest Greenland over the last two millennia using the concentration of deoxycholic acid in a sedimentary sequence retrieved from Lake Igaliku (Figure 4). The flux of deoxycholic acid correlated quantitatively with that of coprophilous fungal spores, with maximum flux recorded during the two periods of human settlement and grazing activity in the region (i.e., the Norse settlement during the Middle Ages and the recent Danish agricultural phase since 1920).

Another paleolimnological application of fecal sterols comes from the study by D'Anjou et al. (2012), who used these molecular markers as a record of prehistoric human and livestock presence in the sedimentary archive of Lake Liland (Lilandsvatnet, Norway). The arrival of humans in northern Norway is indicated by an abrupt increase in coprostanol (and its epimer epicoprostanol) and an associated increase in 5 $\beta$-stigmastanol (and 5 $\beta$-epistigmastanol), which resulted from human and animal feces washing into the lake. Human settlement was accompanied by an abrupt increase in landscape fires (indicated by the rise in pyrolytic PAHs) and a decline in woodland (registered by a change in $n$-alkane chain lengths).

Recently, Giguet-Covex et al. (2014) used an approach based on DNA metabarcoding of lake sediments to provide a highresolution reconstruction of plant cover and livestock farming in the catchment of Lake Anterne (French Alps). The presence of cattle and sheep DNA in the lake sediments indicates intense pasturing activity with mixed herds in the catchment during the Late Iron Age and Roman Period, as well as during the second half of the Middle Ages. By comparing these data with a previous reconstruction of erosive event frequency (GiguetCovex et al., 2011), the authors showed that the most intense erosion period was caused by deforestation and overgrazing by sheep and cowherds during the Late Iron Age and Roman Period.

\section{LIMITATIONS AND PITFALLS OF THE BIOMARKER APPROACH}

We have illustrated the use of biomarker molecules as paleoecological indicators of human activities in Sections Biomarker Evidence of Environmental Changes that can be Linked to Human Disturbances and Unambiguous Biomarkers of Human Activities. All paleoecological "tools" depend on 


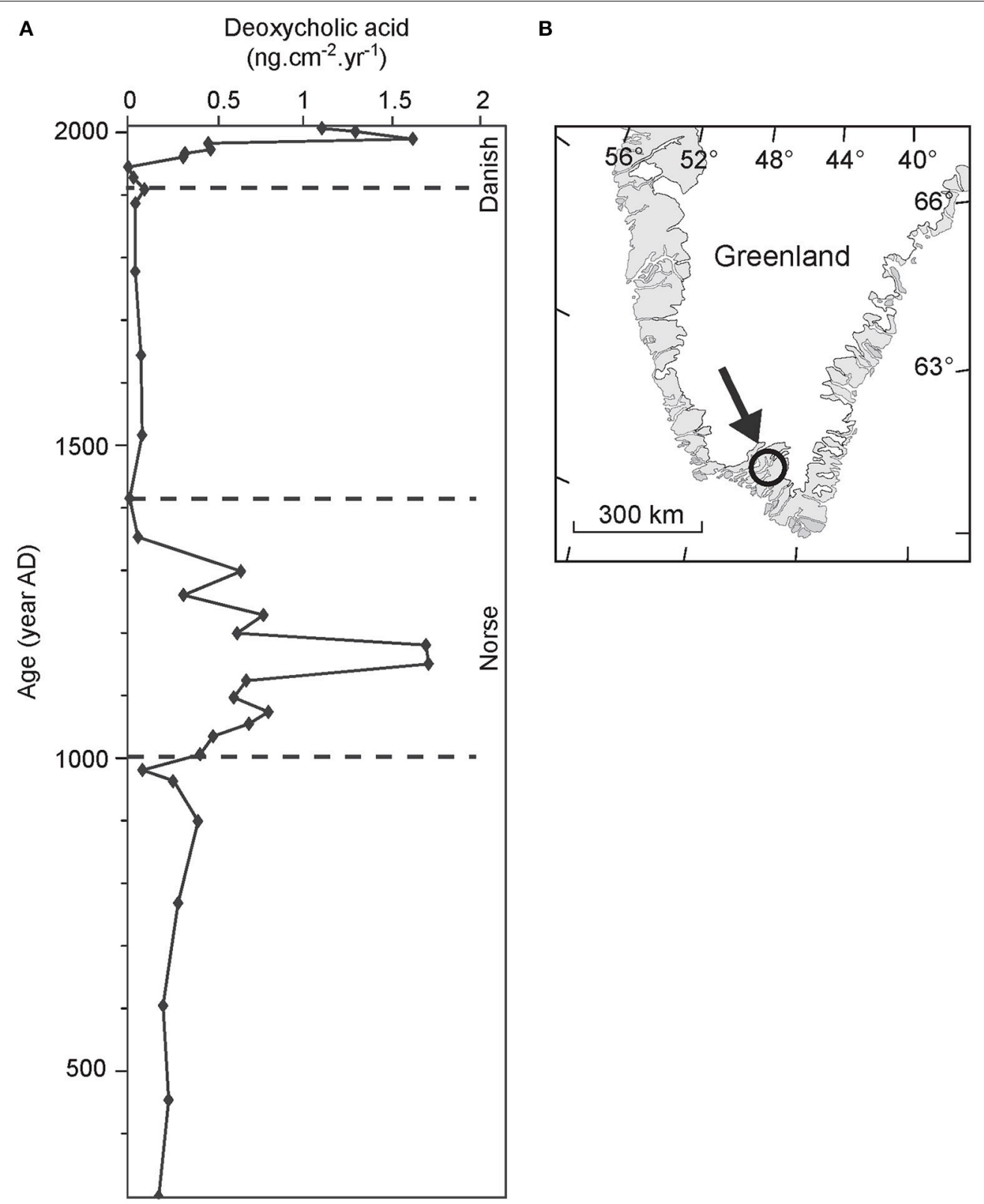

FIGURE 4 | (A) Evolution of deoxycholic acid in the sediments of Lake Igaliku in relationship with Norse and Danish colonization and breeding; (B) Location of Lake Igaliku (Greenland). Modified from Guillemot et al. (2015).

assumptions, and biomarkers are no exception. Many questions remain for biomarker studies, some of which are already mentioned in the preceding examples. In the following, we discuss the general challenges of biomarkers, regarding their source, transport and post-depositional processes and will then take use the miliacin record in Lake Le Bourget (France) as a specific example.

\section{Source-Related Issues}

The ideal biomarker has one single specific source, for instance cannabinol (Section Cultivation). This desire, however, is rarely met. Most organic compounds retrieved from natural archives have multiple sources, some more specific than others (e.g., PTMEs for Graminae vs. leaf waxes for any terrestrial plant). It is thus assumed that a biomarker is specific to a given taxa as long as there is no counter-example. The more specific, the more useful a biomarker is for tracing human-related processes. More detailed studies of the organic compounds in the contemporary biosphere will further "ground-truth" the biomarker approaches.

The most problematic pitfall regarding source material is when there are additional and/or unknown sources of the biomarker of interest, as is the case for branched GDGTs or 
TTHC (see Section Soil erosion). Changes in the production or proportion of additional sources can influence the preserved record and thus the final interpretation, but these can often be corrected. For instance, for $n$-alkanes, the potential contribution from bacterial/algal inputs or contamination with petroleum can be assessed using the relative abundance of odd-over-even $n$ alkanes or the relative abundance of higher molecular-weight components (see Section Vegetation shifts, Pancost and Boot, 2004).

\section{Quantitative Representativeness}

Absolute concentrations in biomarkers are rarely discussed in terms of biomass of its source organisms since they depend on production, transport, sedimentation, and post-deposition processes. Instead, changes in the relative intensity of the signal, or the presence/absence of a biomarker are preferably interpreted and discussed.

The first issue related with quantification is the extent to which environmental factors (e.g., sunlight for plants, fire temperature for fire biomarkers) influence the production of the biomarker over time. The common assumption is that this effect is negligible in comparison to changes in the distribution of the source organism.

The transport mechanisms of biomarkers can also affect its representativeness and should always be assessed in the depositional setting under investigation. Both rivers and wind transport large amounts of terrestrial organic material to the lakes and oceans repositories. The proportion of terrestrial biomarker derived from aeolian as opposed to fluvial processes is geographically variable and variable over time at any given site. In addition, the mode of transport depends on the biomarker source: fire biomarkers will essentially be transported by wind, whereas soil and plant biomarkers dominantly experience fluvial transport. These modes of transport have obviously an impact on the deposition area of the biomarker. The fact that transport processes and catchment areas of biomarkers and microfossils differ can prove very useful in multi-proxy reconstructions. Indeed, when taken into account, the different types of indicators can provide complementary information. For instance, macroscopic charcoal is usually transported only a few $100 \mathrm{~m}$ to a few kilometers and is thus mostly a local fire proxy (Whitlock and Larsen, 2001), whereas levoglucosan can be transported as an aerosol hundreds of kilometers and is therefore a regional to hemispheric fire proxy (Zennaro et al., 2014). The opposite is true for pollen and plant biomarker, with pollen having a larger catchment area than biomarker (e.g., Jansen et al., 2013; Garel et al., 2014).

Transport time can also be a source of uncertainties in the biomarker record. For instance, plant waxes have been shown to be transported from continent to ocean in days to weeks (Conte and Weber, 2002), but molecular radiocarbon ages have revealed that some compounds can reside for thousands of years in soils (Eglinton et al., 2002). There is also radiocarbon evidence for long biomarker transit times during fluvial transport (Drenzek, 2007). These residence times in intermediate reservoirs such as soils, river, and littoral sediments can result in lags of the biomarker record compared to more rapidly deposited coarser material, but can be assessed by molecular radiocarbon analyses.

In conclusion, the terrestrial biomarkers transferred from land have to be considered in terms of both the catchment areas that supply them and the selectivity and rates of transfer and deposition by the transport processes. For more detailed reviews of the controls on biomarker transport, we refer the reader to Pancost and Boot (2004) and Eglinton and Eglinton (2008).

\section{Degradation}

Degradation could alter or attenuate the molecular stratigraphic record. However, biomarkers have been shown to be highly persistent compounds. The strong covalent bonds, $\mathrm{C}-\mathrm{C}$ and $\mathrm{C}-\mathrm{H}$, which characterize most of the compounds used as biomarkers, are very difficult to break without high energy input such as heating at high temperatures, radical attack, or through the highly specific activity of enzymes and other catalysts (Eglinton and Eglinton, 2008). Most biomarkers thus survive passage through food web processes (Volkman et al., 1980), consolidation, and the effects of diagenesis (Brassell and Eglinton, 1981). Thus, this type of molecule tends to pass intact through the environment and is conserved in sediments over geological time. We use the following case study from Lake le Bourget (France) to further discuss questions related to the representativeness of molecular biomarkers of human activities, and thus explore the extent to which such a record can be interpreted.

\section{Case Study}

Since the data published by Jacob et al. (2009), the resolution of the miliacin record in core LDB04 has been considerably improved for the Bronze Age (Figure 5). In addition, it has been replicated by another miliacin record on core LDB01, drilled 4 $\mathrm{km}$ away in the same lake (Figure 1A). The first striking feature is the comparable evolution of miliacin concentrations over the Bronze Age in the two cores. This implies that miliacin was homogeneously distributed in sediments over the lake (at least at $4 \mathrm{~km}$ of distance). Few changes in detritism over the interval exclude varying dilution by the mineral matrix (see Arnaud et al., 2005; Debret et al., 2010). Since miliacin is considered, as with most pentacyclic triterpenes, to be an antifungal and antibacterial agent, changes in early diagenesis can also be discarded. The main control on miliacin concentration in sediments must thus be related to incoming fluxes of this biomarker.

The second interesting feature is the marked transition in miliacin concentrations. For example, the drastic decrease in miliacin concentrations noted around $800 \mathrm{BC}$ is rapid and synchronous in both cores. It coincides with the abandonment of Bronze Age villages around the lake (the youngest dendrochronological date on a wooden pile corresponds to 805 BC; Billaud, 2012), associated with a major lake level rise (Magny, 2004). This implies a limited time lag between villages' abandonment and the decrease in miliacin concentration. This also suggests that there is an immediate (considering the timescale) transport of miliacin from the site of cultivation to the sediment, with limited residence time in soils. This observation is also valid for other marked transitions at 1250, 1200, 1100, 1150, and $850 \mathrm{BC}$. Our running hypothesis is that most of the miliacin 


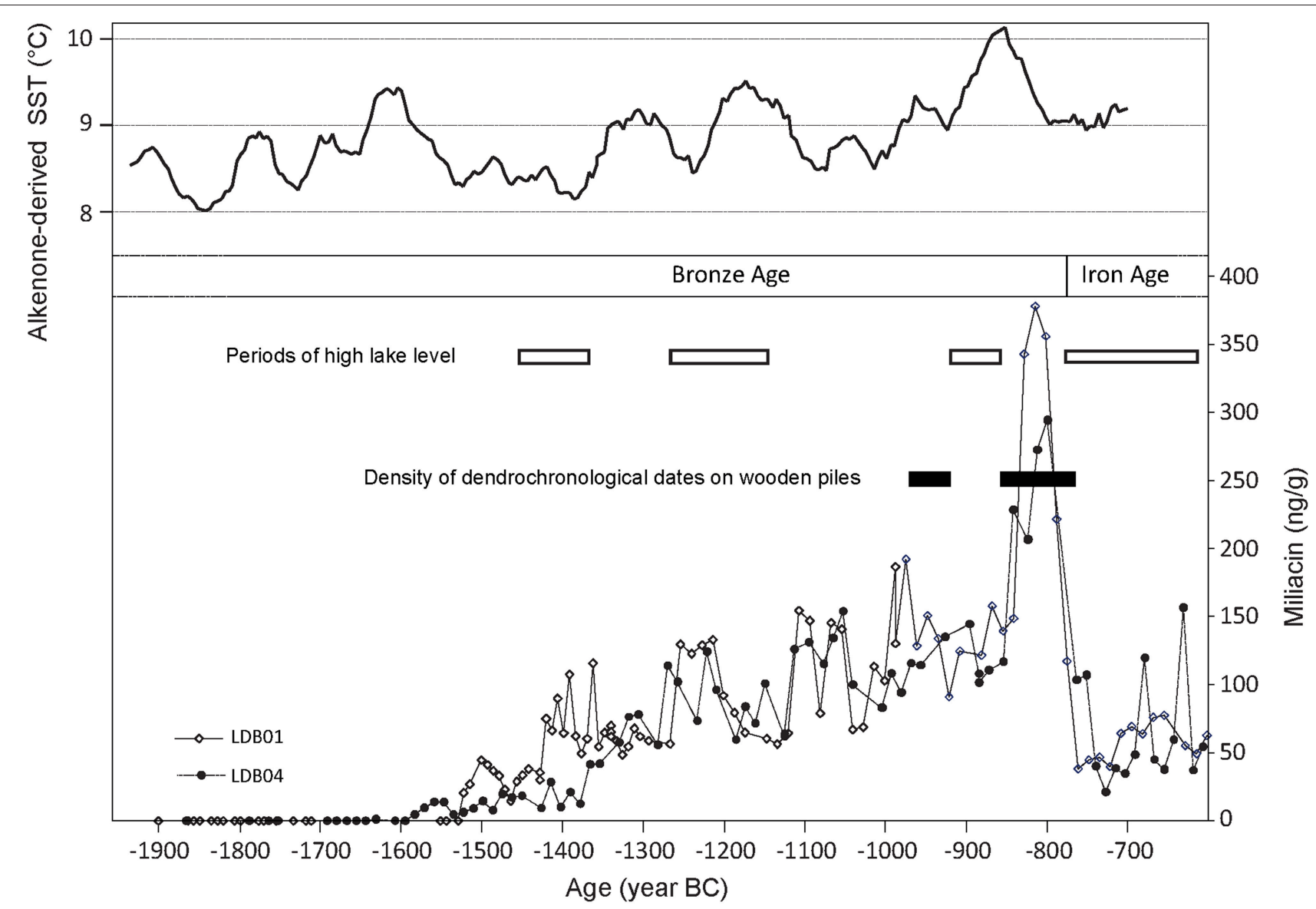

FIGURE 5 | Evolution of miliacin concentration in cores LDB01 and LDB04 from Lake le Bourget (Savoie, France). Cores LDB01 and LDB04 were collected in 2001 and 2004, respectively, at 4 km distance and benefit from independent age models (Arnaud et al., 2005; Debret et al., 2010). Miliacin concentrations are compared to Sea Surface Temperatures as reconstructed from alkenones paleothermometry north of Iceland (Sicre et al., 2008b), to the density of dendrochronological dates measured on wooden piles on various palafittic sites around Lake le Bourget (Billaud, 2012) and to high levels of Lake le Bourget as reconstructed by Magny (2004).

produced in the catchment was directly and quantitatively transported to the sediment. Bossard et al. (2013) showed that miliacin is essentially concentrated in millet seeds. Hence, miliacin transport is related to millet seed transport. In this case, ethnography provides very pertinent information. Poissonnier (1995) reported that millet harvesting was not performed with a sickle but with a dedicated knife, panicle by panicle, to avoid any loss. Therefore, one could expect limited fall of millet seeds, and thus miliacin, during harvesting. Miliacin was therefore directly transported to the villages, sites of millet preparation and consumption. Since villages were located on the shores, miliacin was then directly released to the lake and dispersed above the sediment.

Except for the 850-800 BC interval (with values higher than $350 \mathrm{ng} / \mathrm{g}$ ), most miliacin concentration values oscillate between ca. 75 and $150 \mathrm{ng} / \mathrm{g}$. As mentioned above, absolute concentrations in biomarkers are rarely discussed. But one could question the origin of such recurrent doublings of miliacin concentrations in Lake le Bourget sediments. The period of maximum miliacin concentration coincides with the maximum density of dendrochronological dates measured on wooden piles (Figure 5) and is considered as the period of maximum population density around the lake (Billaud, 2012). It is thus tempting to relate miliacin concentrations with demography, as millet was staple food for Late Bronze Age populations (the "Golden Age" of millet; Marinval, 1995). However, it is not known whether miliacin production by the plant changes with climate conditions. Varying miliacin concentrations would thus attest to varying millet production due to varying needs from populations of varying size. We currently have no information on whether millet was solely used for human or also cattle consumption and no information on the proportion of millet in diet. Thus, these two explanations for varying miliacin cannot be discarded. However, the pace of climate variability, as depicted by high lake levels (Magny, 2004) and, more distant, sea surface temperatures in Northern Iceland (that proved connected to climate evolution in Europe; Sicre et al., 2008a,b) shows puzzling similarities with that of the miliacin record. Periods 
of high temperatures coincide roughly with periods of high miliacin concentrations. A causal link between climate variations affecting demography and millet consumption is highly attractive but still speculative and should be confirmed. In summary, the correlation of large shifts in concentration with village abandonment, lake level variations, and overall climate indicates that miliacin concentration could potentially track demographic changes possibly under climate control, but this needs to be confirmed.

\section{OUTLOOK/FUTURE DIRECTIONS}

The development and application of biomarkers for unraveling the impacts of human activities constitutes by nature an interdisciplinary challenge that must be overcome through crosscollaboration. Several questions raised here are of concern not only for organic geochemists, but also for a large array of disciplines (e.g., sedimentology, archaeology, and paleoecology...).

Combining continuous sedimentological records of minerogenic supply, past upper vegetation disturbance, soil erosion, and molecular markers with historical and archaeological evidences (e.g., Simonneau et al., 2013) will allow the calendar of human disturbances on ecosystems to be refined, and help define more precisely the significance of biomarkers in the sedimentary record. The large spectrum of compounds of interest detected in archaeological (Evershed et al., 1999; Evershed, 2008) sites and artifacts could constitute a source of inspiration for paleoenvironmentalists analysing sedimentary records. The reverse also applies. For example, miliacin is increasingly used as a tracer of millet processing or storage in archaeological sites (Lu et al., 2009).

Developments in individual biomarker ${ }^{14} \mathrm{C}$ dating will also constitute a revolution in biomarkers studies. It will allow the age of biomarkers to be compared with that of the surrounding sediment, providing information on the residence time of biomarkers in the soil carbon pool (Drenzek, 2007; Galy et al., 2011; Feng et al., 2013) and probably quantify soil degradation through time.

Biomarkers released in large amounts due to human activities may have altered or modified the functioning of ecosystems. In the case of hemp retting, ecosystem alteration has been noted, but the specific role of cannabinol, for example on past microbial communities, has not been explored. Similarly, considering the recognized activities of miliacin, more attention should be paid to the impact of this new compound in watersheds and specifically on biological communities.

Last but not least, all biomarkers described here are natural compounds, of which the presence/abundance in natural archives has been modified by human activities. But as paleoenvironmentalists move toward the Anthropocene window, they become confronted with xenobiotics, foreign chemical substances that are not normally naturally produced. Integrating those xenobiotics as tracers of recent human activities will allow: (1) bringing together paleoenvironmentalists and people working on pollutants dynamics, since they share similar concerns (source, reactivity, spatial, and temporal variability of target compounds); and (2) explore more anthropized socioecosystems such as cities, and focus on temporal scales even more relevant for citizens and decision makers.

\section{CONCLUSION}

Human land use has profoundly transformed ecosystems but determining the timing, intensity, and distribution of human impact remains challenging. Only in rare cases do unequivocal tracers of human activity allow disentangling natural events from human induced impacts.

Novel approaches based on molecular markers have been developed recently to reconstruct the history of anthropogenic activities. Among the unequivocal indicators of anthropogenic activity that enable human impacts to be distinguished from the effects of climate change, we find cultivation specific biomarkers and fecal biomarkers. Prime examples of cultivation biomarkers include miliacin, a PTME specific of the broomcorn millet, or cannabinol, which indicates not only hemp cultivation but more extensively hemp retting. Fecal biomarkers such as coprostanol or bile acids have been used to confirm the presence of humans and grazing animals through time.

The fossil molecules that reflect environmental changes possibly attributable to humans include: (1) organic components directly emitted in smoke particulate matter (e.g., PAHs, BPCA or levoglucosan), which would reflect the use of fire; (2) lignin phenols and plant waxes-including their distribution and isotopic composition-which reflect vegetation changes, in particular clearance to make way for agriculture; (3) biomarkers reflecting human induced soil-erosion, including TTHC as well as branched GDGTs (specific biomarkers for soil); and finally (4) algal and microbial biomarkers that reflect changes in the aquatic ecosystem such as the contribution of autochtonous vs. allochtonous organic matter (e.g., short chain $n$-alkanes, sterols).

Molecular markers turn out to be particularly useful in settings where the information from macrofossil indicators is not available or the material is too badly decomposed for the recognition of macrofossils. In best cases scenarios where the macrofossil record is well preserved, biomarkers provide useful complementary tools in multi-proxy approaches, confirming the macrofossil results or even providing additional information.

Last but not least, fossil DNA offers new perspectives but necessitates further development.

\section{AUTHOR CONTRIBUTIONS}

All authors listed, have made substantial, direct and intellectual contribution to the work, and approved it for publication.

\section{ACKNOWLEDGMENTS}

The authors wish to thank Renata Zocatelli, Marlène Lavrieux, Typhaine Guillemot, Anaëlle Simmoneau, Yves Billaud, MarieAlexandrine Sicre and Fabien Arnaud for the permission 
to use their figures/data. S. Nemiah Ladd kindly proof-read this manuscript. C. Le Milbeau, N. Bossard, J. R. Disnar and R. Boscardin largely contributed to the LBD01 and LDB04 miliacin data, acquired within the frame of the Aphrodyte (ECLISPE 2005-2006), Pygmalion (ANR BLAN07-2_204489), PalHydroMil (ANR-2010-JCJC-607-01), ERODE (EC2CO, CNRS/INSU), OTARIE (Région Centre, European Council) and Paléochamps (AIR Archéométrie, CNRS/INSU) projects. ND

\section{REFERENCES}

Abe, I., Rohmer, M., and Prestwich, G. D. (1993). Enzymatic cyclization of squalene and oxidosqualene to sterols and triterpens. Chem. Rev. 93, 2189-2208. doi: $10.1021 / \mathrm{cr} 00022 \mathrm{a} 009$

Andersson, R. A., Kuhry, P., Meyers, P., Zebühr, Y., Crill, P., and Mörth, M. (2011). Impacts of paleohydrological changes on $n$-alkane biomarker compositions of a Holocene peat sequence in the eastern European Russian Arctic. Org. Geochem. 42, 1065-1075. doi: 10.1016/j.orggeochem.2011.06.020

Anselmetti, F. S., Hodell, D. A., Ariztegui, D., Brenner, M., and Rosenmeier, M. F. (2007). Quantification of soil erosion rates related to ancient Maya deforestation. Geology 35, 915-918. doi: 10.1130/G23834A.1

Arnaud, F., Revel, M., Chapron, E., Desmet, M., and Tribovillard, N. (2005). 7000 years of Rhône river flooding activity in Lake Le Bourget: a Highresolution sediment record of NW Alps hydrology. Holocene 15, 420-428. doi: 10.1191/0959683605hl801rp

Arnaud, F., Révillon, S., Debret, M., Revel, M., Chapron, E., Jacob, J., et al. (2012). Lake Bourget regional erosion patterns reconstruction reveals Holocene NW European Alps soil evolution and paleohydrology. Quat. Sci. Rev. 51, 81-92. doi: 10.1016/j.quascirev.2012.07.025

Behre, K. E. (1981). The interpretation of anthropogenic indicators in pollen diagrams. Pollen Spores 23, 225-245.

Bertrand, O., Mansuy-Huault, L., Montargès-Pelletier, E., Losson, B., Argant, J., Ruffaldi, P., et al. (2012). Molecular evidence for recent land use change from a swampy environment to a pond (Lorraine, France). Org. Geochem. 50, 1-10. doi: 10.1016/j.orggeochem.2012.06.004

Billaud, Y. (2012). "Le lac du Bourget à la fin de l'ßge du Bronze. Premiers éléments pour une reconstitution de l'occupation des zones littorales Dans," in L'homme au Bord de l'eau: Archéologie des Zones Littorales du Néolithique à la Protohistoire. Actes du $135^{e}$ congrès CTHS «Paysages》, Neuchatel, avril 2010, eds M. Honegger and C. Mordant (Cahiers d'Archéologie Romande 132), 345-361.

Blyth, A. J., Asrat, A., Baker, A., Gulliver, P., Leng, M. J., and Genty, D. (2007). A new approach to detecting vegetation and land-use change using highresolution lipid biomarker records in stalagmites. Quat. Res. 68, 314-332. doi: 10.1016/j.yqres.2007.08.002

Bossard, N., Jacob, J., Milbeau, C. L., Sauze, J., Terwilliger, V., Poissonnier, B., et al. (2013). Distribution of miliacin (olean-18-en-3 $\beta$-ol methyl ether) and related compounds in broomcorn millet (Panicum miliaceum) and other reputed sources: implications for the use of sedimentary miliacin as a tracer of millet. Org. Geochem. 63, 48-55. doi: 10.1016/j.orggeochem.2013.07.012

Bourbonnière, R. A., and Meyers, P. A. (1996). Sedimentary geolipid records of historical changes in the watersheds and productivities of Lakes Ontario and Erie. Limnol. Oceanogr. 41, 352-359. doi: 10.4319/lo.1996.41.2.0352

Brassell, S. C., and Eglinton, G. (1981). "Steroids and triterpenoids in deep sea sediments as environmental and diagenetic indicators," in Advances in Organic Geochemistry, eds M. Bjoroy, P. Albrecht, C. Cornford, K. De Groot, G. Eglinton, E. Galimov, D. Leythaeuser, R. Pelet, J. Rullkötter, and G. Speers (New York, NY: Wiley), 684-697.

Brocks, J. J., and Pearson, A. (2005). Building the biomarker tree of life. Rev. Mineral. Geochem. 59, 233-258. doi: 10.2138/rmg.2005.59.10

Brocks, J., and Summons, R. (2004). "Sedimentary hydrocarbons, biomarkers for early life," in Treatise on Geochemistry, ed R. W. Carlson (Oxford: Elsevier), 63-115. gratefully acknowledges funding from the Swiss National Science Foundation PALEOFARM grant 200021_160066/1.

\section{SUPPLEMENTARY MATERIAL}

The Supplementary Material for this article can be found online at: http://journal.frontiersin.org/article/10.3389/fevo. 2016.00092
Bull, I. D., Lockheart, M. J., Elhmmali, M. M., Roberts, D. J., and Evershed, R. P. (2002). The origin of faeces by means of biomarker detection. Environ. Int. 27, 647-654. doi: 10.1016/S0160-4120(01)00124-6

Chikaraishi, Y., Naraoka, H., and Poulson, S. R. (2004). Hydrogen and carbon isotopic fractionations of lipid biosynthesis among terrestrial (C3, C4 and CAM) and aquatic plants. Phytochemistry 65, 1369-1381. doi: 10.1016/j.phytochem.2004.03.036

Combettes, C., Sémah, A.-M., and Wirrmann, D. (2015). High-resolution pollen record from Efate Island, central Vanuatu: Highlighting climatic and human influences on Late Holocene vegetation dynamics. C. R. Palevol. 14, 251-261. doi: 10.1016/j.crpv.2015.02.003

Conte, M. H., and Weber, J. C. (2002). Long-range atmospheric transport of terrestrial biomarkers to the western North Atlantic. Global Biogeochem. Cycles 16, 89-1-89-17. doi: 10.1029/2002GB001922

Cranwell, P. A. (1973). Chain-length distribution of $n$-alkanes from lake sediments in relation to post-glacial environmental change. Freshw. Biol. 3, 259-265. doi: 10.1111/j.1365-2427.1973.tb00921.x

Cranwell, P. A. (1982). Lipids of aquatic sediments and sedimenting particulates. Prog. Lipid Res. 21, 271-308. doi: 10.1016/0163-7827(82)90012-1

D'Anjou, R. M., Bradley, R. S., Balascio, N. L., and Finkelstein, D. B. (2012). Climate impacts on human settlement and agricultural activities in northern Norway revealed through sediment biogeochemistry. Proc. Natl. Acad. Sci. U.S.A. 109, 20332-20337. doi: 10.1073/pnas.1212730109

Davis, O. K., and Shafer, D. S. (2006). Sporormiella fungal spores, a palynological means of detecting herbivore density. Palaeogeogr. Palaeoclim. Palaeoecol. 237, 40-50. doi: 10.1016/j.palaeo.2005.11.028

Dearing, J. A. (2008). Landscape change and resilience theory: a palaeoenvironmental assessment from Yunnan, SW China. Holocene 18, 117-127. doi: 10.1177/0959683607085601

Dearing, J. A., Battarbee, R. W., Dikau, R., Larocque, I., and Oldfield, F. (2006). Human-environment interactions: learning from the past. Reg. Environ. Change 6, 1-16. doi: 10.1007/s10113-005-0011-8

Debret, M., Chapron, E., Desmet, M., Rolland-Revel, M., Magand, O., Trentesaux, A., et al. (2010). North western Alps Holocene paleohydrology recorded by flooding activity in Lake Le Bourget, France. Quat. Sci. Rev. 29, 2185-2200. doi: 10.1016/j.quascirev.2010.05.016

Denis, E. H., Toney, J. L., Tarozo, R., Scott, A. R., Roach, L. D., and Huang, Y. (2012). Polycyclic aromatic hydrocarbons (PAHs) in lake sediments record historic fire events: validation using HPLC-fluorescence detection. Org. Geochem. 45, 7-17. doi: 10.1016/j.orggeochem.2012. 01.005

Diamond, J. (2002). Evolution, consequences and future of plant and animal domestication. Nature 418, 700-707. doi: 10.1038/nature01019

Drenzek, N. I. (2007). The Temporal Dynamics of Terrestrial Organic Matter Transfer to the Oceans: Initial Assessment and Application, Ph.D. thesis, MITWHOI.

Eglinton, G., and Calvin, M. (1967). Chemical fossils. Sci. Am. 216, 32-43. doi: 10.1038/scientificamerican0167-32

Eglinton, T. I., and Eglinton, G. (2008). Molecular proxies for paleoclimatology. Earth Planet. Sci. Lett. 275, 1-16. doi: 10.1016/j.epsl.2008.07.012

Eglinton, T. I., Eglinton, G., Dupont, L., Sholkovitz, E. R., Montluçon, D., and Reddy, C. M. (2002). Composition, age and provenance of organic matter in NW African dust over the Atlantic Ocean. Geochem. Geophys. Geosyst. 3:GC000269. doi: 10.1029/2001gc000269 
Elias, V. O., Simoneit, B. R. T., Cordeiro, R. C., and Turcq, B. (2001). Evaluating levoglucosan as an indicator of biomass burning in Carajas, amazonia: a comparison to the charcoal record. Geochim. Cosmochim. Acta 65, 267-272. doi: 10.1016/S0016-7037(00)00522-6

Evershed, R. P. (2008). Organic residue analysis in archaeology: the archaeological biomarker revolution. Archaeometry 50, 895-924. doi: 10.1111/j.14754754.2008.00446.x

Evershed, R. P., Dudd, S. N., Charters, S., Mottram, H., Stott, A. W., Raven, A., et al. (1999). Lipids as carriers of anthropogenic signals from prehistory. Phil. Trans. R. Soc. Lond. B 354, 19-31. doi: 10.1098/rstb.1999.0357

Feng, X., Jorien, E., Vonk, J. E., van Dongen, B. E., Gustafsson, O., Semiletov, I. P., et al. (2013). Differential mobilization of terrestrial carbon pools in Eurasian Arctic river basins. Proc. Natl. Acad. Sci. U.S.A. 110, 14168-14173. doi: $10.1073 /$ pnas. 1307031110

Fisher, E., Oldfield, F., Wake, R., Boyle, J., Appleby, P., and Wolff, G. A. (2003). Molecular marker records of land use change. Org. Geochem. 21, 105-119. doi: 10.1016/S0146-6380(02)00145-6

Foley, S. F., Gronenborn, D., Andreae, M. O., Kadereit, J. W., Esper, J., Scholz, D., et al. (2013). The Palaeoanthropocene-the beginnings of anthropogenic environmental change. Anthropocene 3, 83-88. doi: 10.1016/j.ancene.2013.11.002

Freeman, D. J., and Cattell, F. C. R. (1990). Woodburning as a source of atmospheric polycyclic aromatic hydrocarbons. Environ. Sci. Technol. 24, 1581-1585. doi: 10.1021/es00080a019

Galeron, M. A., Volkman, J. K., and Rontani, J. F. (2016). Oxidation products of betulin: new tracers of abiotic degradation of higher plant material in the environment. Org. Geochem. 91, 31-42. doi: 10.1016/j.orggeochem.2015.10.010

Galy, V., Eglinton, T., France-Lanord, C., and Sylva, S. (2011). The provenance of vegetation and environmental signatures encoded in vascular plant biomarkers carried by the Ganges-Brahmaputra rivers. Earth Planet. Sci. Lett. 304, 1-12. doi: 10.1016/j.epsl.2011.02.003

García-Falcón, M. S., Soto-Gonzalez, B., and Simal-Gandara, J. (2006). Evolution of the concentrations of polycyclic aromatic hydrocarbons in burnt woodland soils. Environ. Sci. Technol. 40, 759-763. doi: 10.1021/es051803v

Garel, S., Quesnel, F., Jacob, J., Roche, E., Le Milbeau, C., Dupuis, C., et al. (2014). High frequency floral changes at the Paleocene-Eocene Boundary revealed by comparative biomarker and palynological studies. Org. Geochem. 77, 43-58. doi: 10.1016/j.orggeochem.2014.09.005

Gauthier, E., and Richard, H. (2009). Bronze age at Lake Bourget (NW Alps, France): vegetation, human impact and climatic change. Quat. Int. 200, 111-119. doi: 10.1016/j.quaint.2008.10.004

Giguet-Covex, C., Arnaud, F., Poulenard, J., Disnar, J. R., Delhon, C., Francus, P., et al. (2011). Changes in erosion patterns during the Holocene in a currently treeless subalpine catchment inferred from lake sediment geochemistry (Lake Anterne, $2063 \mathrm{~m}$ a.s.l., NW French Alps): the role of climate and human activities. Holocene 21, 651-665. doi: 10.1177/0959683610391320

Giguet-Covex, C., Pansu, J., Arnaud, F., Rey, P.-J., Griggo, C., Gielly, L., et al. (2014). Long livestock farming history and human landscape shaping revealed by lake sediment DNA. Nat. Commun. 5:3211. doi: 10.1038/ncomms4211

Glikson, A. (2013). Fire and human evolution: the deep-time blueprints of the Anthropocene. Anthropocene 3, 89-92. doi: 10.1016/j.ancene.2014.02.002

Grimalt, J. O., Yruela, I., Saiz-Jimenez, C., Toja, J., de Leeuw, J. W., and Albaigés, J. (1991). Sedimentary lipid biogeochemistry of an hypereutrophic alkaline lagoon. Geochim. Cosmochim. Acta 55, 2555-2577. doi: 10.1016/00167037(91)90373-D

Guilaine, J. (1991). "Vers une préhistoire agraire," in Pour une Archéologie Agraire, ed J. Guilaine (Paris: Armand Colin), 31-80.

Guilaine, J. (2000). Changeons d'échelles: pour la très longue durée, pour de larges espaces. Études Rurales 153/154, 9-21. Available online at: http://etudesrurales. revues.org/1

Guillemot, T., Zocatelli, R., Bichet, V., Jacob, J., Massa, C., Le Milbeau, C., et al. (2015). Evolution of pastoralism in Southern Greenland during the last two millennia reconstructed from bile acids and coprophilous fungi spores in lacustrine sediments. Org. Geochem. 81, 40-44. doi: 10.1016/j.orggeochem.2015.01.012

Harvey, E. L., and Fuller, D. Q. (2005). Investigating crop processing using phytolith analysis: the example of rice and millets. J. Archaeol. Sci. 32, 739-752. doi: $10.1016 /$ j.jas.2004.12.010
Hauke, V., Graff, R., Wehrung, P., Trendel, J. M., Albrecht, P., Riva, A., et al. (1992b). Novel triterpene-derived hydrocarbons of arborane/fernane series in sediments. Part II. Geochim. Cosmochim. Acta 56, 3595-3602.

Hauke, V., Graff, R., Wehrung, P., Trendel, J. M., Albrecht, P., Schwark, L., et al. (1992a). Novel triterpene-derived hydrocarbons of arborane/fernane series in sediments. Part I. Tetrahedron 48, 3915-3924.

Hopmans, E. C., Weijers, J. W. H., Schefuß, E., Herfort, L., Sinninghe Damsté, J. S., and Schouten, S. (2004). A novel proxy for terrestrial organic matter in sediments based on branched and isoprenoid tetraether lipids. Earth Planet. Sci. Lett. 224, 107-116. doi: 10.1016/j.epsl.2004.05.012

Huang, X., Meyers, P. A., Wu, W., Jia, C., and Xie, S. (2011). Significance of long chain iso and anteiso monomethyl alkanes in the Lamiaceae (mint family). Org. Geochem. 42, 156-165. doi: 10.1016/j.orggeochem.2010.11.008

Jacob, J., Disnar, J.-R., Arnaud, F., Chapron, E., Debret, M., Lallier-Vergès, E., et al. (2008a). Millet cultivation history in the French Alps as evidenced by a sedimentary molecule. J. Archaeol. Sci. 35, 814-820. doi: 10.1016/j.jas.2007.06.006

Jacob, J., Disnar, J.-R., Arnaud, F., Gauthier, E., Billaud, Y., Chapron, E., et al. (2009). Impacts of new agricultural practices on soil erosion during the Bronze Age in the French Prealps. Holocene 19, 241-249. doi: $10.1177 / 0959683608100568$

Jacob, J., Disnar, J.-R., and Bardoux, G. (2008b). Carbon isotope evidence for sedimentary miliacin as a tracer of Panicum miliaceum (broomcorn millet) in the sediments of Lake le Bourget (French Alps). Org. Geochem. 39, 1077-1080. doi: 10.1016/j.orggeochem.2008.04.003

Jacob, J., Disnar, J.-R., Boussafir, M., Spadano Albuquerque, A. L., Sifeddine, A., and Turcq, B. (2005). Pentacyclic triterpene methyl ethers in recent lacustrine sediments (Lagoa do Caçó, Brazil). Org. Geochem. 36, 449-461. doi: 10.1016/j.orggeochem.2004.09.005

Jaffé, R., and Hausmann, K. B. (1995). Origin and early diagenesis of arborinone/isoarborinol in sediments of a highly productive freshwater lake. Org. Geochem. 22, 231-235. doi: 10.1016/0146-6380(95)90020-9

Jansen, B., de Boer, E. J., Cleef, A. M., Hooghiemstra, H., Moscol-Olivera, M., Tonneijck, F. H., et al. (2013). Reconstruction of late Holocene forest dynamics in northern Ecuador from biomarkers and pollen in soil cores. Palaeogeogr. Palaeoclim. Palaeoecol. 386, 607-619. doi: 10.1016/j.palaeo.2013. 06.027

Lavrieux, M. (2011). Biomarqueurs Moléculaires D'occupation des sols, du sol au Sédiment: Exemple du Bassin-versant et du lac d'Aydat (Puy-de-Dôme). Ph.D. thesis, Université de Tours, Orléans.

Lavrieux, M., Jacob, J., Disnar, J. R., Bréheret, J. G., Le Milbeau, C., Miras, Y., et al. (2013). Sedimentary cannabinol tracks the history of hemp retting. Geology 41, 751-754. doi: 10.1130/G34073.1

Lavrieux, M., Jacob, J., Le Milbeau, C., Zocatelli, R., Masuda, K., Bréheret, J. G., et al. (2011). Occurrence of triterpenyl acetates in soil and their potential as chemotaxonomical markers of Asteraceae. Org. Geochem. 42, 1315-1323. doi: 10.1016/j.orggeochem.2011.09.005

Lehndorff, E., Jörg Linstädter, J., Kehl, M., and Weniger, G.-C. (2014). Fire history reconstruction from Black Carbon analysis in Holocene cave sediments at Ifri Oudadane, Northeastern Morocco. Holocene 25, 398-402. doi: $10.1177 / 0959683614558651$

Le Milbeau, C., Lavrieux, M., Jacob, J., Bréheret, J.-G., Zocatelli, R., and Disnar, J.-R. (2013). Methoxy-serratenes in a soil under a conifer forest and their potential use as biomarkers of Pinaceae. Org. Geochem. 55, 45-54. doi: 10.1016/j.orggeochem.2012.11.008

Logan, G. A., Smiley, C. J., and Eglinton, G. (1995). Preservation of fossil leaf waxes in association with their source tissues, Clarkia, northern Idaho, USA Clarkia, northern Idaho, USA. Geochim. Cosmochim. Acta 59, 751-763. doi: 10.1016/0016-7037(94)00362-P

Lu, H., Zhang, J., Liu, K. B., Wu, N., Li, Y., Zhou, K., et al. (2009). Earliest domestication of common millet (Panicum miliaceum) in East Asia extended to 10,000 years ago. Proc. Natl. Acad. Sci. U.S.A. 106, 7367-7372. doi: $10.1073 /$ pnas.0900158106

Magny, M. (2004). Holocene climate variability as reflected by mid European lakelevel fluctuations and its probable impact on prehistoric human settlements. Quat. Int. 113, 65-79. doi: 10.1016/S1040-6182(03)00080-6

Magny, M., Leroux, A., Bichet, V., Gauthier, E., Richard, H., and WalterSimonnet, A.-V. (2013). Climate, vegetation and land use as drivers of Holocene 
sedimentation: a case study from Lake Saint-Point (Jura Mountains, eastern France). Holocene 23, 137-147. doi: 10.1177/0959683612455550

Malawska, M., Bojakowska, I., and Wiłkomirski, B. (2002). Polycyclic aromatic hydrocarbons (PAHs) in peat and plants from selected peat-bogs in the northeast of Poland. J. Plant Nutr. Soil Sci. 165, 686-691. doi: 10.1002/jpln.200 290004

Marinval, P. (1995). "Données carpologiques françaises sur les Millets (Panicum miliaceum L. et Setaria italica L. Beauv.) de la Protohistoire au Moyen Age," in Millet. Actes du Congrès d'Aizenay (1990), ed E. Hörandner (Frankfurt: Peter Lang), 31-61.

Marseille, F., Disnar, J. R., Guillet, B., and Noack, Y. (1999). n-Alkanes and free fatty acids in humus and A1 horizons of soils under beech, spruce and grass in the Massif-Central (Mont-Lozère), France. Eur. J. Soil Sci. 50, 433-441. doi: 10.1046/j.1365-2389.1999.00243.x

Massa, C., Bichet, V., Gauthier, É., Perren, B. B., Mathieu, O., Petit, C., et al. (2012). A 2500 year record of natural and anthropogenic soil erosion in South Greenland. Quat. Sci. Rev. 32, 119-130. doi: 10.1016/j.quascirev.2011.11.014

Mercuri, A. M., Accorsi, C. A., and Mazzanti, M. B. (2002). The long history of Cannabis and its cultivation by the Romans in central Italy, shown by pollen records from Lago Albano and Lago di Nemi. Vegetation Hist. Archaeobotany 11, 263-276. doi: 10.1007/s003340200039

Meyers, P. A. (2003). Applications of organic geochemistry to paleolimnological reconstructions: a summary of examples from the Laurentian Great Lakes. Org. Geochem. 34, 261-289. doi: 10.1016/S0146-6380(02)00168-7

Miras, Y., Beauger, A., Lavrieux, M., Berthon, V., Serieyssol, K., Andrieu-Ponel, V., et al. (2015). Tracking long-term human impacts on landscape, vegetal biodiversity and water quality in the Lake Aydat catchment (Auvergne, France) using pollen, non-pollen palynomorphs and diatom assemblages. Palaeogeogr. Palaeoclim. Palaeoecol. 424, 76-90. doi: 10.1016/j.palaeo.2015. 02.016

Motuzaite-Matuzeviciute, G., Jacob, J., Telizhenko, S., and Jones, M. K. (2016). Miliacin in palaeosols from an Early Iron Age in Ukraine reveal in situ cultivation of broomcorn millet. Archaeol. Anthropol. Sci. 8, 43-50. doi: $10.1007 /$ s12520-013-0142-7

Muri, G., Wakeham, S. G., Pease, T. K., and Faganeli, J. (2004). Evaluation of lipid biomarkers as indicators of changes in organic matter delivery to sediments from Lake Planina, a remote mountain lake in NW Slovenia. Org. Geochem. 35, 1083-1093. doi: 10.1016/j.orggeochem.2004.06.004

Naeher, S., Peterse, F., Smittenberg, R. H., Niemann, H., Zigah, P. K., and Schubert, C. J. (2014). Glycerol dialkyl glycerol tetraethers (GDGTs) in and around Lake Rotsee (Switzerland): I. Sources of GDGTs and implications for the application of GDGT-based proxies in lakes. Org. Geochem. 66, 164-173. doi: 10.1016/j.orggeochem.2013.10.017

Nishimura, M. (1977). Origin of stanols in young lacustrine sediments. Nature 270, 711-712. doi: 10.1038/270711a0

Nishimura, M., and Koyama, T. (1977). The occurrence of stanols in various living organisms and the behavior of sterols in contemporary sediments. Geochim. Cosmochim. Acta 41, 379-385. doi: 10.1016/0016-7037(77)90265-4

Noël, H., Garbolino, E., Brauer, A., Lallier-Vergès, E., de Beaulieu, J.-L., and Disnar, J. R. (2001). Human impact and soil erosion during the last 5000 years as recorded in lacustrine sedimentary organic matter at Lac d'Annecy, the French Alps. J. Paleolimnol. 25, 229-244. doi: 10.1023/A:1008134517923

Oldfield, F., and Dearing, J. A. (2003). "The role of human activities in past environmental change", in Global Change - The IGBP Series Paleoclimate, Global Change and the Future, eds K. D. Alverson, R. Bradley, and T. F. Pedersen (Berlin Heidelberg: Springer-Verlag), 143-162.

Oros, D. R., and Simoneit, B. R. T. (2001). Identification and emission factors of molecular tracers in organic aerosols from biomass burning Part 1. Temperate climate conifers. Appl. Geochem. 16, 1513-1544. doi: 10.1016/S0883-2927(01)00021-X

Oyo-Ita, O. E., Ekpo, B. O., Oros, D. R., and Simoneit, B. R. T. (2010). Occurrence and sources of triterpenoid methyl ethers and acetates in sediments of the Cross-River system, Southeast Nigeria. Int. J. Anal. Chem. 2010, 1-8. doi: $10.1155 / 2010 / 502076$

Pancost, R. D., Baas, M., van Geel, B., and Sinninghe Damsté, J. S. (2002). Biomarkers as proxies for plant inputs to peats: an example from a subboreal ombrotrophic bog. Org. Geochem. 33, 675-690. doi: 10.1016/S01466380(02)00048-7
Pancost, R. D., and Boot, C. S. (2004). The palaeoclimatic utility of terrestrial biomarkers in marine sediments. Marine Chem. 92, 239-261. doi: 10.1016/j.marchem.2004.06.029

Parducci, L., Jørgensen, T., Tollefsrud, M. M., Elverland, E., Alm, T., Fontana, S. L., et al. (2012). Glacial survival of boreal trees in northern Scandinavia. Science 335, 1083-1086. doi: 10.1126/science.1216043

Peltzer, E. T., and Gagosian, R. B. (1989). Organic geochemistry of aerosols over the Pacific Ocean. Chem. Geol. 10, 281-338.

Pohl, M. E. D., Piperno, D. R., Pope, K. O., and Jones, J. G. (2007). Microfossil evidence for pre-Columbian maize dispersals in the neotropics from San Andres, Tabasco, Mexico. Proc. Natl. Acad. Sci. U.S.A. 104, 6870-6875. doi: 10.1073/pnas.0701425104

Poissonnier, B. (1995). "Le premier millet en France: récolte et mouture suivant l'archéologie et l'expérimentation," in Millet. Actes du Congrès d'Aizenay (1990), ed E. Hörandner (Frankfurt: Peter Lang), 63-70.

Prartono, T., and Wolff, G. A. (1998). Organic geochemistry of lacustrine sediments: a record of the changing trophic status of Rostherne Mere, U.K. Org. Geochem. 28, 729-747. doi: 10.1016/S0146-6380(98)00016-3

Raper, D., and Bush, M. (2009). A test of Sporormiella representation as a predictor of megaherbivore presence and abundance. Quat. Res. 71, 490-496. doi: 10.1016/j.yqres.2009.01.010

Regnery, J., Püttmann, W., Koutsodendris, A., Mulch, A., and Pross, J. (2013). Comparison of the paleoclimatic significance of higher land plant biomarker concentrations and pollen data: a case study of lake sediments from the Holsteinian interglacial. Org. Geochem. 61, 73-84. doi: 10.1016/j.orggeochem.2013.06.006

Rommerskirchen, F., Plader, A., Eglinton, G., Chikaraishi, Y., and Rullkötter, J. (2006). Chemotaxonomic significance of distribution and stable carbon isotopic composition of long-chain alkanes and alkan-1-ols in C4 grass waxes. Org. Geochem. 37, 1303-1332. doi: 10.1016/j.orggeochem.2005.12.013

Ruddiman, W. F. (2013). Anthropocene. Annu. Rev. Earth Planet. Sci. 41, 45-68. doi: 10.1146/annurev-earth-050212-123944

Russo, E. B. (2007). History of Cannabis and its preparations in saga, science, and sobriquet. Chem. Biodiv. 4, 1614-1648. doi : 10.1002/cbdv.200790144

Sanders, G., Jones, K. C., Hamilton-Taylor, J., and Dorr, H. (1995). PCB and PAH fluxes to a dated peat core. Env. Pollut. 89, 17-25. doi: 10.1016/02697491(94)00048-I

Schwab, V. F., Garcin, Y., Sachse, D., Todou, G., Séné, O., Onana, J.-M., et al. (2015). Effect of aridity on $\delta^{13} \mathrm{C}$ and $\delta \mathrm{D}$ values of $\mathrm{C} 3$ plant- and C4 graminoid-derived leaf wax lipids from soils along an environmental gradient in Cameroon (Western Central Africa). Org. Geochem. 78, 99-109. doi: 10.1016/j.orggeochem.2014.09.007

Schwark, L., Zink, K., and Lechterbeck, J. (2002). Reconstruction of post-glacial to early Holocene vegetation history in terrestrial Central Europe via cuticular lipid biomarkers and pollen records from lake sediments. Geology 30, 463-466. doi: 10.1130/0091-7613(2002)030<0463:ROPTEH > 2.0.CO;2

Schüpbach, S., Kirchgeorg, T., Colombaroli, D., Beffa, G., Radaelli, M., Kehrwald, N. M., et al. (2015). Combining charcoal sediment and molecular markers to infer a Holocene fire history in the Maya Lowlands of Petén, Guatemala. Quat. Sci. Rev. 115, 123-131. doi: 10.1016/j.quascirev.2015.03.004

Sicre, M. A., Jacob, J., Ezat, U., Rousse, S., Kissel, C., Pascal Yiou, P., et al. (2008a). Decadal variability of sea surface temperatures off North Iceland over the last 2000 yrs. Earth Planet. Sci. Lett. 268, 137-142. doi: 10.1016/j.epsl.2008.01.011

Sicre, M. A., Yiou, P., Eiríksson, J., Ezat, U., Guimbaut, E., Dahhaoui, I., et al. (2008b). A 4500-year reconstruction of sea surface temperature variability at decadal time-scales off North Iceland. Quat. Sci. Rev. 27, 2041-2047. doi: 10.1016/j.quascirev.2008.08.009

Silliman, J. E., and Schelske, C. L. (2003). Saturated hydrocarbons in the sediments of Lake Apopka, Florida. Org. Geochem. 34, 253-260. doi: 10.1016/S01466380(02)00169-9

Simoneit, B. R. T., Grimalt, J. O., Wang, T. G., Cox, R. E., Hatcher, P. G., and Nissenbaum, A. (1985). Cyclic ternpenoids of contemporary resinous plant detritus and of fossil woods, ambers and coals. Org. Geochem. 10, 877-889. doi: 10.1016/S0146-6380(86)80025-0

Simonneau, A., Doyen, E., Chapron, E., Millet, L., Vannière, B., Di Giovanni, C., et al. (2013). Holocene land-use evolution and associated soil erosion in the French Prealps inferred from Lake Paladru sediments and archaeological evidences. J. Archaeol. Sci. 40, 1636-1645. doi: 10.1016/j.jas.2012.12.002 
Simpson, I. A., Bol, R., Bull, I. D., Evershed, R. P., Petzke, K.-J., and Dockrill, S. J. (1999b). Interpreting early land management through compound specific stable isotope analyses of archaeological Soils. Rapid Commun. Mass Sp. 13, 1315-1319.

Simpson, I., van Bergen, P. F., Perret, V., Elhmmali, M. M., Roberts, D. J., and Evershed, R. P. (1999a). Lipid biomarkers of manuring practice in relict anthropogenic soils. Holocene 9, 223-229.

Tinner, W., Lotter, A. F., Ammann, B., Conedera, M., Hubschmid, P., van Leeuwen, J. F. N., et al. (2003). Climatic change and contemporaneous land-use phases north and south of the Alps 2300 BC to 800 AD. Quat. Sci. Rev. 22, 1447-1460. doi: 10.1016/s0277-3791(03)00083-0

Trendel, J. M., Schaeffer, P., Adam, P., Ertlen, D., and Schwartz, D. (2010). Molecular characterization of soil surface horizons with different vegetation in the Vosges Massif (France). Org. Geochem. 41, 1036-1039. doi: 10.1016/j.orggeochem.2010.04.014

van Bergen, P. F., Bull, I. D., Poulton, P. R., and Evershed, R. P. (1997). Organic geochemical studies of soils from the Rothamsted classical experiments: I total lipid extracts, solvent insoluble residues and humic acids from broadbalk wilderness. Org. Geochem. 26, 117-135. doi: 10.1016/S0146-6380(96) 00134-9

Vane, C. H., Rawlins, B. G., Kim, A. W., Moss-Hayes, V., Kendrick, C. P., and Leng, M. J. (2013). Sedimentary transport and fate of polycyclic aromatic hydrocarbons $(\mathrm{PAH})$ from managed burning of moorland vegetation on a blanket peat, South Yorkshire, U.K. Sci. Total Environ. 449, 81-94. doi: 10.1016/j.scitotenv.2013.01.043

Volkman, J. K., Corner, E. D. S., and Eglinton, G. (1980). "Transformations of biolipids in the marine food web and in underlying bottom sediments," in Colloques Internationaux. Centre Nationale de la Recherche Scientifique n. 293, ed R. Daumas (Paris: Editions Centre Nationale de la Recherche Scientifique), 185-197.

Wakeham, S. G., Schaffner, C., and Geiger, W. (1980). Polycyclic aromatic hydrocarbons in recent lake sediments - II. Compounds derived from biogenic precursors during early diagenesis. Geochim. Cosmochim. Acta 44, 415-429. doi: 10.1016/0016-7037(80)90041-1

Whitlock, C., and Larsen, C. (2001). "Charcoal as a fire proxy," in Tracking Environmental Change Using Lake Sediments, eds J. P. Smol, H. J. B. Birks, W. M. Last (Dordrecht: Kluwer Academic Publishers), $1-23$.
Whittington, G., and Gordon, A. D. (1987). The differentiation of the pollen of Cannabis sativa L. from that of Humulus lupulus L. Pollen Spores 29, 111-120.

Wurster, C. M., Bird, M. I., Bull, I. D., Creed, F., Bryant, C., Jennifer, A. J., et al. (2010). Forest contraction in north equatorial Southeast Asia during the Last Glacial Period. Proc. Natl Acad. Sci. U.S.A. 107, 15508-15511. doi: 10.1073/pnas.1005507107

Xie, S., Wang, Z., Chen, F., and An, C. (2002). The occurrence of a grassy vegetation over the Chinese loess plateau since the last interglacial: the molecular fossil record. Sci. China Ser. D 45, 53-62. doi: 10.1007/BF02879696

Xu, Y., Jaffé, R., and Simoneit, B. R. T. (2008). Oxygenated spiro-triterpenoids possibly related to arborenes in sediments of a tropical, freshwater lake. Org. Geochem. 39, 1400-1404. doi: 10.1016/j.orggeochem.2008.07.003

Zalasiewicz, J., Waters, C. N., Williams, M., Barnosky, A. D., Cearreta, A., Crutzen, P., et al. (2015). When did the Anthropocene begin? A mid-twentieth century boundary level is stratigraphically optimal. Quat. Int. 383, 196-203. doi: 10.1016/j.quaint.2014.11.045

Zennaro, P., Kehrwald, N., McConnell, J. R., Schüpbach, S., Maselli, O. J., Marlon, J., et al. (2014). Fire in ice: two millennia of boreal forest fire history from the Greenland NEEM ice core. Clim. Past 10, 1905-1924. doi: 10.5194/cp-10-19052014

Zocatelli, R., Jacob, J., Gogo, S., Le Milbeau, C., Rousseau, J., Laggoun-Défarge, F., (2014). Variability of soil lipids reflects vegetation cover in a French peatland. Org. Geochem. 76, 173-183. doi: 10.1016/j.orggeochem.2014.07.016

Zocatelli, R., Jacob, J., Turcq, B., Boussafir, M., Sifeddine, A., and Bernardes, M. C. (2010). Biomarker evidence for recent turf cultivation in Northeast Brazil (Lagoa do Boqueiryo, RN State). Org. Geochem. 41, 427-430. doi: 10.1016/j.orggeochem.2009.12.008

Conflict of Interest Statement: The authors declare that the research was conducted in the absence of any commercial or financial relationships that could be construed as a potential conflict of interest.

Copyright (c) 2016 Dubois and Jacob. This is an open-access article distributed under the terms of the Creative Commons Attribution License (CC BY). The use, distribution or reproduction in other forums is permitted, provided the original author(s) or licensor are credited and that the original publication in this journal is cited, in accordance with accepted academic practice. No use, distribution or reproduction is permitted which does not comply with these terms. 